\title{
Classical and Innovative Insulin Sensitizing Drugs for the Prevention and Treatment of NAFLD
}

\author{
Lucia Carulli, Mauro Maurantonio, Lionel Hebbard*, Enrica Baldelli, Paola Loria and George Jacob*
}

Department of Internal Medicine, Endocrinology, Metabolism and Geriatrics, Nuovo Ospedale Civile Sant'Agostino-Estense of Modena, University of Modena and Reggio Emilia, Italy; *Storr Liver Unit, Westmead Millennium Institute, University of Sydney and Westmead Hospital, Westmead, New South Wales 2145, Australia.

\begin{abstract}
Background. Nonalcoholic fatty liver disease (NAFLD), the most common chronic liver disorder worldwide, comprises a spectrum of conditions ranging from simple steatosis to nonalcoholic steatohepatitis (NASH) and cirrhosis. NASH is associated with an increased risk of hepatocellular carcinoma (HCC) and cardiometabolic disease. Insulin resistance (IR) is the underlying pathogenic mechanism for NAFLD, the presence of which in turn, is a strong predictor for the development of metabolic disorders. Hence, therapy of NAFLD with insulin-sensitizing drugs (ISDs) should ideally improve the key hepatic histological changes (steatosis, inflammation and fibrosis), but should also reduce cardiometabolic and cancer risk.

Objectives. In this review, the rationale for the use of ISDs and the evidence for their efficacy are detailed. In particular, the mechanism of action, potential for use, limitations and untoward effects of metformin and thiazolidinediones are systematically reviewed. Further, we discuss novel ISDs that may have potential clinical utility in NAFLD.

Results and Conclusion. Despite the theoretical prediction that ISDs might have beneficial effects on disease outcomes, evidence that ISDs are able to alter the natural history of NAFLD are presently not available. The exploration of novel strategies exploiting "nonconventional" ISDs is encouraged.
\end{abstract}

Keywords: Adiponectin; dipeptidyl peptidase-IV inhibitors; estrogens; glucagon-like peptide-1; hepatocellular carcinoma; insulin sensitizing drugs; metformin; nonalcoholic fatty liver disease; rimonabant; thiazolidinediones; ursodeoxycholic acid.

\section{BACKGROUND}

Nonalcoholic Fatty Liver Disease (NAFLD), a spectrum of disorders ranging from simple steatosis to nonalcoholic steatohepatitis (NASH) with/without cirrhosis, and hepatocellular carcinoma (HCC) [1] is the most common chronic liver disease, with a prevalence of $25 \%$ in the general population of Western Countries [2].

The prevalence of NAFLD is increased in subjects with type 2 diabetes mellitus (35\%-90\%), obesity (10\%-80\%), hypertension (30\%-56\%) and dyslipidemia (26\%-58\%)[3]. Age, gender and ethnicity also influence NAFLD prevalence; NAFLD is more common in older subjects and in males, but prevalence rates could be an underestimate given the often suboptimal diagnostic methods used [4]. The prevalence of hepatic steatosis in the Dallas Heart Study followed a clear-cut gradient with Hispanics being more affected than whites, and African Americans ranking as the ethnic group with the least prevalence of NAFLD [5]. A more recent analysis confirmed that ethnicity represents a major determinant for the risk of developing NASH for a given level of insulin resistance (IR) [6]. Primary NAFLD is typically associated with IR and the Metabolic Syndrome (MetS) [7]. Diagnosis requires the exclusion of other causes of liver disease such as viral infection, autoimmune diseases, alcohol abuse, endocrine and genetic disorders [8].

NAFLD is an early predictor of metabolic disorders, even in non-diabetic and non-obese subjects [9]. It is associated with an increased risk for all cause mortality, end-stage liver disease, cardiovascular disease, HCC and some hepatic and extrahepatic cancers [10,12-20]. Despite the relative accuracy of non-invasive methods for predicting advanced fibrosis [10], liver biopsy remains the gold-standard for the grading and staging of NAFLD [2,11].

*Address correspondence to this author at the Storr Liver Unit, Westmead Millennium Institute, University of Sydney and Westmead Hospital, Westmead, New South Wales 2145, Australia; Tel:/Fax: ????????????????????; E-mail: jacob.george@sydney.edu.au
In animal studies, a direct progression from steatosis to NASH has been observed, leading to speculation that "multiple hits" are involved in the pathophysiology of a single disease spanning a wide spectrum. However, more recent views support the concept that simple steatosis and NASH appear as two distinct entities and progression from pure fatty liver to NASH appears to be so rare as to warrant publication [84]

The ideal treatment for NAFLD should improve the key histological changes of NASH (steatosis, inflammation and fibrosis) and reduce morbidity and mortality from cardiometabolic diseases and cancer, particularly HCC [14,21]. Diabetic patients are known to have a high prevalence of NAFLD/NASH [22] and are recognized to be at higher risk for HCC [23-30 ]. Additionally, in diabetics, $50 \%$ of cases of HCC develop in non-cirrhotic livers [31-33] and overall, only $46 \%$ of patients with NAFLD and HCC have been shown to have cirrhosis [34]. The putative mechanisms underlying the development of HCC in NAFLD relate to IR and to the associated inflammatory cascade [35]. Hence, Insulin-sensitizing drugs (ISDs) might be effective in preventing NAFLD-associated HCC, but data to confirm or refute this assertion are still awaited.

ISDs therapy of NASH has been extensively investigated. However, most trials are relatively small, proof-of-concept studies. The largest body of data in humans is available for two classes of ISDs: thiazolidinediones (TZDs) and biguanides.

In the present review, the rationale for the use, and data on the efficacy for both ISD classes will be detailed. Next, we discuss more innovative therapies that, acting through insulin sensitization, hold promise for clinical utility in NAFLD and therefore need to be validated by testing in the clinical arena.

\section{SECTION 1. SHOULD WE TREAT INSULIN RESISTANCE TO CURE NAFLD?}

\section{A). Pathogenesis of IR}

IR may be defined in multiple ways but eventually results in impaired response to insulin actions. The pathogenesis of IR resides 
in imbalanced energy homeostasis leading to ectopic lipid accumulation [36]. Physical inactivity, excess caloric intake and altered dietary composition are key exogenous factors that promote the development of a fatty liver which, in turn, promotes IR [37-43].

At the molecular level, hyperglycemia associated with hyperinsulinemia promotes the development of hepatic steatosis via upregulation of the lipogenic transcription factors including sterol regulatory element binding protein-1 (SREBP-1) and peroxisome proliferator-activated receptor gamma (PPAR- $\gamma$ ), and their downstream effector enzymes acetyl-CoA carboxylase (ACC) and fatty acid synthase (FAS) [44].

In the adipose tissue, impaired insulin-mediated inhibition of hormone-sensitive lipase is conducive to increased circulating levels of free fatty acids (FFA) [45], which also closely correlate with liver fat content and can further promote hepatic IR [46]. Therefore, in humans, peripheral and hepatic IR are closely interrelated. Recent data on the role of the endocrine system and the hypothalamus in the development of and worsening of IR have been reviewed elsewhere [47].

\section{B). The Role of IR in the Development of NAFLD and Cardio- vascular Disease}

Epidemiological studies suggest a strong relationship between IR and CVD in nondiabetic subjects [48]. IR is associated with dyslipidemia and other abnormalities, including oxidative stress, endothelial dysfunction and release of proinflammatory cytokines, that all contribute to the pathogenesis of CVD [49]

Similarly, IR plays a major role in the development and progression of NAFLD [50-53]. In the EGIR RISC Study, an ongoing prospective multicentre project involving a large European Caucasian population of non-diabetic subjects aiming to evaluate the relationship between IR and cardiovascular risk, fatty liver was associated with IR, higher Framingham risk scores and increased intimamedia thickness suggesting an increased risk for CHD [54]. In turn, hepatic steatosis causes the release of pro-inflammatory cytokines such as Interleukin-6 (IL-6) and tumor necrosis factor- $\alpha$ (TNF- $\alpha$ ) that contribute to fibrosis progression [55-57] and to premature arterial aging, hence the concept of an "atherogenic liver" [53].

The complex mechanisms that govern the development of steatosis and NASH, including host genetic variability, intestinal dysbiosis, adipose tissue dysfunction and intrahepatic molecular and cellular changes are beyond the scope of this review [58]. However, as IR is an independent risk factor for the development of NASH, it represents an ideal (but not the only) therapeutic target to prevent and treat NAFLD [50,59-61].

\section{C). The Role of IR in the Development of HCC}

For HCC occurring in the context of NAFLD/NASH, insulin and Insulin-like Growth Factor (IGF) type I receptor family (IIRF) are recognized to play a role in promoting tumor growth $[62,63]$. Most cancer types express both the insulin receptor and IGF genes, which represent a tyrosine-kinase class of membrane receptors that are homologous to oncogenes of the tyrosine-kinase class $[64,65]$. Similarly, there is a relationship between cancer and obesity, and cancer risk is closely associated with weight gain, hyperinsulinemia and IR [66-69]. Finally, IR leads to the release of multiple proinflammatory, oncogenic cytokines (such as Interleukin-6, tumor necrosis factor- $\alpha$ ), while hyperinsulinemia stimulates the production of IGF-1 that promotes cellular proliferation and a reduction in apoptosis $[70,71]$.

\section{D). Why Treat IR in NASH?}

There are several cogent reasons for treating IR associated with NASH. First, IR is almost universal in NASH [50], which is associated with liver-related mortality and cardiovascular disease [1,72]. Second, patients with NASH are at a higher risk for developing
HCC particularly if T2D coexists [73]. Whether and to what extent ISDs prevent HCC is a key question in the management of NAFLD. Third, IR contributes to the development and progression of both $\mathrm{NASH}$ and atherosclerosis in subjects with NASH. With regard to the latter, it is of interest that metformin reduces vascular stiffness in patients with NAFLD, further to, and independent of glycemic control [74].

\section{E). Effects of Current Treatments of IR on NAFLD}

Lifestyle changes that promote weight loss (diet and exercise) and bariatric surgery have proven effective in improving IR and reducing the extent of liver steatosis [75,76].

A $7-10 \%$ weight loss with intensive multidisciplinary lifestyle intervention is associated with improving hepatic steatosis, NAFLD activity score (NAS) but not fibrosis [77]. Likewise, exercise increases hepatic and extra-hepatic AMPK mediated non-esterified fatty acid oxidation, reduces post-prandial hepatic lipogenesis and proinflammatory cytokines release, reduces liver steatosis and improves ALT levels [78]. Physical exercise also improves glucose metabolism, insulin sensitivity, and atherogenic dyslipidemia without significantly affecting body weight [79]. In contrast, lowcarbohydrate diets significantly reduces waist circumference further to improving pancreatic beta-cell function, triglyceride levels and insulin sensitivity [80] Weight loss $>10 \%$ seems to be necessary to improve hepatic necroinflammation [81].

Bariatric surgery, indicated to treat severe obesity seems to reduce hepatic steatosis, steatohepatitis and fibrosis, and improves IR. However this form of therapy is not without complications and it is premature to consider foregut bariatric surgery as an established option to specifically treat NASH [82].

Recent analysis, however, is inconclusive as to whether the reduction in IR is sufficient to improve liver histology [83-85].

\section{SECTION 2. METFORMIN IN PREVENTION AND TREATMENT OF NAFLD}

\section{A). Metabolic Effects of Metformin}

Metformin is licensed for the treatment of type 2 diabetes mellitus at the recommended doses of 500-2500 mg daily. The mechanism of action of metformin, an oral biguanide glucose-lowering agent with effects on the mithocondria, has not been fully elucidated, but involves activation of the adenosine monophosphateactivated protein kinase (AMPK) pathway[86]. Activated AMPK, an evolutionarily conserved gauge of intracellular energy depletion, switches cell metabolism from an anabolic to a catabolic state, resulting in the inhibition of glucose, lipid and protein synthesis as well as cellular growth and increased fatty acid $\beta$-oxidation [87]

Glucose metabolism- Metformin decreases intestinal glucose absorption and increases insulin mediated glucose uptake in skeletal muscle by positive effects on insulin receptor, expression and tyrosine-kinase activity [88] . Moreover, metformin seems to increase plasma levels of GLP-1 and to induce islet incretin receptor gene expression through a PPAR- $\alpha$ mediated mechanism [89]. Metformin reduces hepatic gluconeogenesis linking the organic cation transporter 1 (OCT1) in hepatocytes, which facilitates the uptake of metformin [90] The final result is a reduction in hyperinsulinemia [91,9293].

Lipoprotein metabolism- AMPK activation by metformin induces the phosphorylation and inactivation of acetyl CoA carboxylase (ACC), an important rate-controlling enzyme for the synthesis of malonyl-CoA, which is both a critical precursor for the biosynthesis of fatty acids and a potent inhibitor of mitochondrial fatty acid oxidation [94]. Metformin participates in the regulation of lipogenic genes expression by down-regulating sterol regulatory element-binding protein-1c (SREBP-1c) gene expression [95]. As a result of these mechanisms, metformin improves lipoprotein profile 
by decreasing LDL cholesterol levels and triglycerides, and increasing HDL cholesterol.

Others effects- Metformin, by decreasing levels of plasminogen activator inhibitor-1 and increasing tissue plasminogen activator activity, reduces markers of inflammation and levels of advanced glycated end products (AGEs), which are oxidative mediators of endothelial dysfunction [96]. Interestingly, metformin also exerts anti-hypertensive effects [97]. Moreover, compared to insulin, metformin use has recently been associated with a reduced risk of cancer, notably HCC [98-101] (Table 1) [97,99,102-119], to which, as previously mentioned, diabetic patients appear to be particularly vulnerable [14]. Based on these properties, metformin is the "first choice" drug for the treatment of type 2 diabetes mellitus, MetS and polycystic ovary syndrome (PCOS), all conditions typically associated with NAFLD $[106,120]$.

\section{B). Metformin in NAFLD}

Two meta-analyses of randomized-controlled trials (RCTs) have shown that metformin reduces both IR and MetS without improving hepatic histology in NASH [111,112] (Fig. 1) [53].

\section{Biochemical Response}

In a 12-month prospective randomized, placebo-controlled trial comparing diet and exercise alone, to diet and exercise plus metformin in non-diabetic subjects with IR and NASH, metformin (maximum dose $1 \mathrm{gr}$ daily) improved alanine aminotransferase (ALT) levels in all groups treated, but there was no correlation with histological changes $[113,121,122]$. In the Diabetes Prevention Program (DPP) trial, that compared the effects of a program of diet and exercise with treatment with either metformin or placebo in overweight or obese adults with elevated fasting glucose or im- paired glucose tolerance, the improvement in ALT was more sustained if associated with weight reduction. This suggests that the effect of metformin on liver tests and hepatic steatosis is mediated primarily by weight loss $[113,123]$.

\section{Histological Response \\ Steatosis}

Metformin is more effective than diet alone in reducing steatosis [124]. Metformin administered in association with antioxidants leads to a reduction of hepatic steatosis, without improving neither lobular inflammation or hepatocellular ballooning [121].

Elevated levels of Fetuin A, a liver-derived glycoprotein that critically affects key enzymes in lipid and glucose metabolism, impairs insulin signalling and positively correlates with steatosis, IR and MetS, [125]. Metformin reduces in vitro the hepatic expression of Fetuin A suggesting that the metabolic effects of metformin are mediated by Fetuin A [126,127].

\section{Necroinflammation and Fibrosis}

Compared to placebo, treatment with metformin leads to improved liver test and reduced IR without any significant differences in hepatic histology [128].

In one RCT involving nineteen consecutive non-diabetic, but insulin resistant subjects with biopsy proven NASH, no improvement in NAFLD activity score (NAS) [129] or fibrosis was observed, whereas steatosis significantly improved [128]. Similarly in another report of $20 \mathrm{NASH}$ subjects, no improvement in ballooning or lobular inflammation was observed after a 12 month-course of metformin supplemented with the antioxidant methyl donor $\mathrm{N}$ acetyl-cysteine [121].

\section{Table 1: Biological effects of metformin in humans.}

\begin{tabular}{|c|c|c|}
\hline Biological Function Parameter/abnormality & Action of Metformin & Ref \\
\hline Insulin-resistance & reduction & [102-104] \\
\hline Intestinal glucose absorption & reduction & [105] \\
\hline Glucose-lowering & allow & [106] \\
\hline Skeletal Muscle gluconeogenesis & increase & [107] \\
\hline Hepatic gluconeogenesis & reduction & [108] \\
\hline Hyperlipidemia & reduction of total-C, LDL-C and TG levels & {$[109,110]$} \\
\hline Development of the Metabolic Syndrome & reduction & [111] \\
\hline Arterial hypertension & reduction & [97] \\
\hline Improved liver histology in NAFLD & $\uparrow$ & {$[111,112]$} \\
\hline Liver tests & improvement & {$[102,113]$} \\
\hline Cardiovascular risk & reduction & [114-116] \\
\hline Weight gain & reduction & {$[98,99]$} \\
\hline Development of cancer & reduction & {$[80,100]$} \\
\hline
\end{tabular}

Legend: total-C $=$ Total cholesterol; LDL-C $=$ low-density lipoprotein; $\mathrm{TG}=$ triglycerides; $\uparrow=$ null/inconsistent 


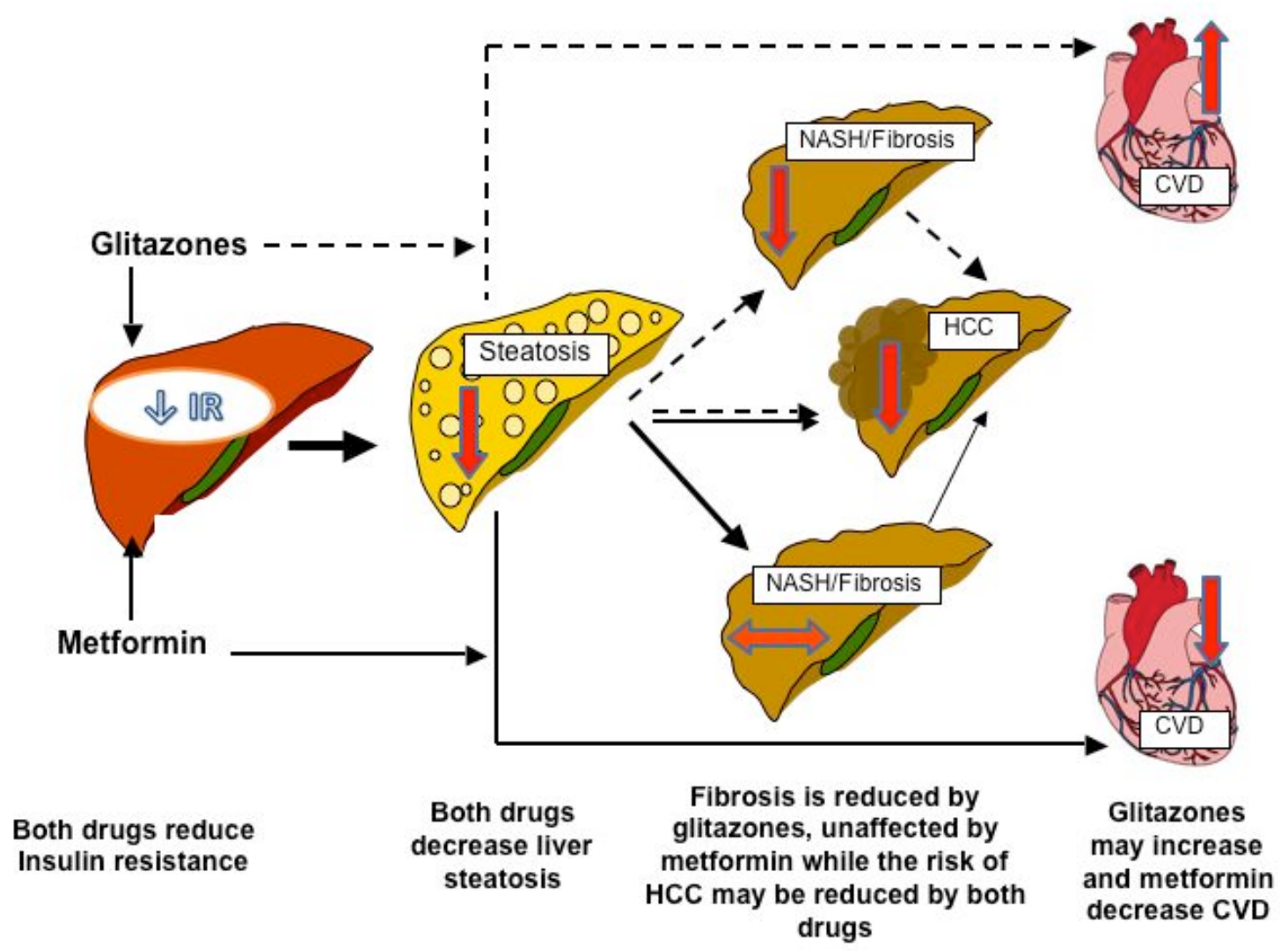

Fig. (1). Mechanisms of action and impact on natural history of NAFLD of glitazones and metformin [53]

Legend to (Fig. 1): Metformin reduces IR via activation of AMPK, reduces liver steatosis, MetS and cardiovascular risk but does not improve liver histology. The PPARs- $\gamma$ (glitazones) reduce IR via activation of multiple pathways, reduce liver steatosis and improve liver histology but are associated with worsening cardiovascular disease. IL- $6=$ Interleukin- 6 ; TNF- $\alpha=$ tumor necrosis factor- $\alpha$; AMPK= 5'adenosine monophosphate-activated protein kinase; HCC $=$ hepatocellular carcinoma; $\mathrm{CVD}=$ cardiovascular disease.

In their open-label RCT comparing the combination of rosiglitazone plus metformin to either drug alone in patients with NASH Omer and colleagues found that after 1 year of treatment, steatosis and necroinflammation significantly improved with rosiglitazone, but not with metformin. The combination of both drugs conferred no additional benefit to liver histology and glucose metabolism [130]. Thus, although it improves IS, metformin might fail to reverse the histological features of NASH. These findings contradict the results from an open label, randomized trial conducted in non diabetic patients, which reported that metformin at doses of $2 \mathrm{mg}$ daily was more effective than either diet or Vitamin $\mathrm{E}$ in reducing steatosis, necroinflammation and fibrosis [113].

Finally, a recent meta-analysis of 78 RCTs confirmed that lifestyle interventions that induce weight loss or pioglitazone, but not metformin, improves liver histology and cardio-metabolic profile [131].

\section{C). Metformin in Subjects with NASH and Increased CVD Risk}

A subclinical proinflammatory state is the hallmark of cardiovascular risk in NAFLD. Compared to healthy controls, these patients typically display, significantly higher serum levels of proinflammatory cytokines such as C-reactive Protein (CRP), interleukin-6, and TNF- $\alpha$. Furthermore, hs-CRP levels are higher in subjects with NASH than in individuals with simple steatosis $[132,133]$. Interestingly, Metformin reduces hs-CRP and contributes to reducing the pro-atherogenic stimulus in subject at higher CVD risk [122]. However, no published data specifically clarify whether metformin reduces CVD risk in subjects with NAFLD/ NASH.

\section{D). Metformin in HCC and Non-hepatic Cancer}

Several observational and biological studies suggest a relationship between the use of metformin and a reduction in the incidence of various cancer types, including those of the breast, colon, ovary, lung and prostate [98,134-138]. Similarly, the use of metformin, compared to the use of sulphonylureas or insulin appears to be associated with a strong and statistically significant reduction in the risk of developing HCC, in diabetic patients [100,101]. The mechanisms for this effect are unclear. However, metformin appears to reduce carcinogenesis, in part, by inhibiting the synthesis of reactive oxygen species (ROS) production as a consequence of its effects on mitochondrial function [139], and by regulating the AMPactivated kinase (AMPK)/mammalian Target of Rapamycin (mTORC1) pathway favoring the anti-proliferative effects of AMPK [140,141]. Whether such a preventive effect is observed in non-diabetic NAFLD patients as well, however, remains to be ascertained.

\section{E). Adverse Effects of Metformin}

Having been used for over 30 years, metformin appears to be remarkably safe, with mild gastrointestinal effects alone in a minority of cases. However, its use is better avoided in case of impaired renal function, sepsis and congestive heart failure as in this context it is associated with a higher risk of lactic acidosis [84].

In conclusion, metformin alone does not appear to be effective for the treatment of NASH, but its use is appropriate in the subgroup of patients with MetS and increased cardiovascular risk. [93,1310,142] (Table 2a) [102,121-123,128,130,143-145]. 
Table 2a: Effect of metformin on liver enzymes and histology in patients with Nonalcoholic Fatty Liver Disease

\begin{tabular}{|c|c|c|c|c|c|c|c|c|}
\hline Author, year & $\begin{array}{l}\text { Daily } \\
\text { Dose }\end{array}$ & Liver Enzymes & Liver Histology & Design & Comment & Duration & $\begin{array}{c}\text { Number } \\
\text { patients }\end{array}$ & $\begin{array}{l}\text { CVD ou- } \\
\text { tcomes }\end{array}$ \\
\hline $\begin{array}{l}\text { Marchesini } \\
\text { G, 2001 } \\
\text { [102] }\end{array}$ & $1,5 \mathrm{~g}$ & improved & Not assessed & $\begin{array}{l}\text { Open label, } \\
\text { single arm }\end{array}$ & Liver volume Reduction & 4 months & 20 & NA \\
\hline $\begin{array}{c}\text { Bugianesi E, } \\
2005[113]\end{array}$ & $2 \mathrm{~g}$ & improved & $\begin{array}{l}\text { Reduction necroin- } \\
\text { flammation }\end{array}$ & $\begin{array}{l}\text { Open label, } \\
\text { RCT }\end{array}$ & Associated weight loss & 12 months & 55 & NA \\
\hline $\begin{array}{l}\text { Uygun A, } \\
2004 \\
{[143]}\end{array}$ & $1,7 \mathrm{~g}$ & improved & $\begin{array}{l}\text { No significative diffe- } \\
\text { rence in necroinflam- } \\
\text { matory activity }\end{array}$ & $\begin{array}{l}\text { Open label, } \\
\text { RCT }\end{array}$ & Associated weight loss & 6 months & 18 & NA \\
\hline $\begin{array}{c}\text { Nobili V, } \\
2008 \\
{[144]}\end{array}$ & 1,5 & improved & No changes in fibrosis & $\begin{array}{l}\text { Open label, } \\
\text { RCT }\end{array}$ & In children with NAFLD & 24 months & 10 & NA \\
\hline $\begin{array}{l}\text { de Oliveira } \\
\text { CP, } 2008 \\
{[121]}\end{array}$ & $1 \mathrm{~g}$ & improved & $\begin{array}{l}\text { No improvement in } \\
\text { inflammation }\end{array}$ & $\begin{array}{l}\text { Open label, } \\
\text { single arm }\end{array}$ & $\begin{array}{l}\text { Benefical effects in Met- } \\
\text { formin + NAC group }\end{array}$ & 12 months & 20 & NA \\
\hline $\begin{array}{l}\text { Idilman R, } \\
2008[122]\end{array}$ & $1,7 \mathrm{~g}$ & improved & $\begin{array}{l}\text { Improved steatosis; not } \\
\text { significant improve- } \\
\text { ment in fibrosis }\end{array}$ & $\begin{array}{l}\text { Open label, } \\
\text { RCT }\end{array}$ & $\begin{array}{l}\text { Benefical effect on meta- } \\
\text { bolic parameters and hs-CRP } \\
\text { levels in Metformin group }\end{array}$ & 12 months & 74 & NA \\
\hline $\begin{array}{l}\text { Haukeland } \\
\text { JW, 2009 } \\
{[145]}\end{array}$ & $2,5-3$ & improved & No improvement & $\begin{array}{l}\text { Open label, } \\
\text { RCT }\end{array}$ & $\begin{array}{l}\text { Reduction in serum lipid and } \\
\text { glucose }\end{array}$ & 6 months & 48 & NA \\
\hline $\begin{array}{c}\text { Shields VW, } \\
2009[128]\end{array}$ & $0,5-1$ & improved & No improvement & $\begin{array}{l}\text { Open label, } \\
\text { RCT }\end{array}$ & $\begin{array}{l}\text { Benefical in metabolic ef- } \\
\text { fects }\end{array}$ & 12 months & 19 & NA \\
\hline $\begin{array}{l}\text { Krakoff J, } \\
2010[123]\end{array}$ & 1,7 & improved & No improvement & $\begin{array}{l}\text { Open label, } \\
\text { RCT }\end{array}$ & $\begin{array}{c}\text { Benefical effect if associated } \\
\text { to weight loss }\end{array}$ & 3 years & 2153 & NA \\
\hline $\begin{array}{c}\text { Omer Z, } \\
2010 \\
{[130]}\end{array}$ & 1,7 & $\begin{array}{l}\text { No improve- } \\
\text { ment }\end{array}$ & No improvement & $\begin{array}{l}\text { Open label, } \\
\text { RCT }\end{array}$ & $\begin{array}{l}\text { Benefical effect in Metfor- } \\
\text { min+Rosiglitazone group }\end{array}$ & 6 months & 64 & NA \\
\hline
\end{tabular}

Legend: $\mathrm{CVD}=$ cardiovascular disease; hs-CRP= high-sensitivity $\mathrm{C}$-reactive Protein; $\mathrm{NA}=$ not assessed; NAC= N-acetyl-cysteine; $\mathrm{RCT}=$ randomized clinical trial.

Its putative role in preventing $\mathrm{HCC}$ in those with type 2 diabetes mellitus adds to the attraction of this agent.

\section{SECTION 3. THIAZOLIDINEDIONES IN THE PREVEN- TION AND TREATMENT OF NAFLD}

\section{A). Metabolic Effects of Thiazolidinediones}

Thiazolidinediones (TZDs or glitazones: pioglitazone and rosiglitazone) are licensed for the treatment of type 2 diabetes mellitus.. Pioglitazone is administered at the recommended doses of 15$45 \mathrm{mg}$ daily in a single dose. Rosiglitazone in administered at the recommended dose of 4-8 $\mathrm{mg}$ daily. TZDs act as agonists of the peroxisome-proliferator activated receptor-gamma (PPAR- $\gamma$ ), a transcription factor that regulates gene expression in liver, adipose, vascular endothelium, and muscle tissue. Physiologically, these agents promote the differentiation of pre-adipocytes into adipocytes and, anatomically, leads to a redistribution of triglycerides from liver and muscle (namely from an ectopic site) to adipose tissue (the physiological reservoir of fat). Clinically, this leads to improved IS, improved glycaemic control, and decreased hepatic steatosis which in art occurs via increased concentrations of the insulin sensitizing anti-steatotic adipokine adiponectin and consequent activation of the AMPK pathway, [146-150]. Recent reports suggest that the use of TZDs is associated with a reduced incidence of HCC in type 2 diabetes mellitus, perhaps via inhibition of promotion and progression of cancer growth [101,151].

There are unfortunately numerous unwanted side effects and potential risks associated with the use of TZDs, including weight gain, fluid retention, increased fracture rate, and possibly excess cardiovascular events [152,153]. (Fig. 1) [53]. This latter is of particularly worrisome given that cardiovascular events are a major complication in the natural history of NAFLD [154]. A recent metaanalysis suggests an excess of bladder cancer in type 2 diabetes 
Table 2b: Effect of glitazones on liver enzymes and histology in patients with Nonalcoholic Fatty Liver Disease

\begin{tabular}{|c|c|c|c|c|c|c|c|c|}
\hline Author, year & Daily Dose & $\begin{array}{c}\text { Liver En- } \\
\text { zymes }\end{array}$ & Liver Histology & Design & Comment & Duration & $\begin{array}{l}\text { Number } \\
\text { patients }\end{array}$ & $\begin{array}{c}\text { CVD ou- } \\
\text { tcomes }\end{array}$ \\
\hline $\begin{array}{l}\text { Sanyal AJ, } \\
2004[156]\end{array}$ & $\begin{array}{l}\text { Pioglitazone } 30 \\
\mathrm{mg}+\text { Vitamin E }\end{array}$ & improved & improved & $\mathrm{RCT}$ & $\begin{array}{l}\text { Combination therapy } \\
\text { was superior to Vita- } \\
\text { min E alone in improv- } \\
\text { ing steatosis, necroin- } \\
\text { flammation and } \\
\text { pericellular fibrosis }\end{array}$ & 6 months & 18 & NA \\
\hline $\begin{array}{c}\text { Belfort, } 2006 \\
\text { [157] }\end{array}$ & $\begin{array}{l}\text { Pioglitazone } 45 \\
\mathrm{mg}+\text { hypocalo- } \\
\text { ric diet }\end{array}$ & improved & $\begin{array}{l}\text { Reduction steatosis and } \\
\text { necroinflammation }\end{array}$ & RCT & $\begin{array}{l}\text { The reduction of fibro- } \\
\text { sis do not differ from } \\
\text { the placebo group. }\end{array}$ & 6 months & 45 & $\begin{array}{l}\text { No adverse } \\
\text { effects }\end{array}$ \\
\hline $\begin{array}{c}\text { Ratziu V, } 2008 \\
{[158]}\end{array}$ & $\begin{array}{c}\text { Rosiglitazone } 8 \\
\mathrm{mg}\end{array}$ & improved & $\begin{array}{c}\text { reduction steatosis but } \\
\text { no improvement in } \\
\text { necroinflammation and } \\
\text { NAS score versus } \\
\text { placebo }\end{array}$ & RCT & $\begin{array}{l}\text { reduction in markers } \\
\text { of insulin resistance } \\
\text { versus placebo }\end{array}$ & 12 months & 63 & $\begin{array}{l}\text { No differen- } \\
\text { ce versus } \\
\text { placebo }\end{array}$ \\
\hline $\begin{array}{l}\text { Aithal GP, } \\
2008 \text { [159] }\end{array}$ & $\begin{array}{l}\text { Pioglitazone } 30 \\
\text { mg + exercise } \\
\text { and diet }\end{array}$ & improved & $\begin{array}{l}\text { improvement in hepa- } \\
\text { tocellular injury, Mal- } \\
\text { lory- Denk bodies and } \\
\text { fibrosis }\end{array}$ & RCT & $\begin{array}{l}\text { increase in weight gain } \\
\text { versus placebo }\end{array}$ & 12 months & 61 & NA \\
\hline $\begin{array}{l}\text { Sanyal AJ, } \\
2010[160]\end{array}$ & $\begin{array}{c}\text { Pioglitazone } 30 \\
\mathrm{mg}\end{array}$ & improved & $\begin{array}{l}\text { improvement in steato- } \\
\text { sis and inflammation, } \\
\text { but no in fibrosis score }\end{array}$ & RCT & No hepatotoxicity & 24 months & 80 & $\begin{array}{l}\text { No differen- } \\
\text { ce versus } \\
\text { placebo }\end{array}$ \\
\hline
\end{tabular}

Legend: $\mathrm{CVD}=$ cardiovascular disease; $\mathrm{NA}=$ not assessed; ; $\mathrm{RCT}=$ randomized clinical trial.

mellitus patients treated with TZDs, in particularly with pioglitazone, [155]but these data need to be confirmed.

\section{B). TZDs in NAFLD}

There has been significant interest in evaluating TZDs to treat NASH. Here we summarize and discuss the results of five RCTs and two open label trials using pioglitazone or rosiglitazone (Table 2b) [156-160]

\section{Metabolic Response}

In nondiabetic patients, pioglitazone induces a significant improvement in IS as assessed by euglycemic clamps or surrogate markers (hyperinsulinemia or homeostasis model assessment [HOMA]) [160,161]. A key issue is whether the improvement in insulin sensitivity correlates with biochemical and/or histological responses. Two studies reported that improved hepatic insulin sensitivity was mirrored by aminotransferase reduction [157], and improved surrogate markers of systemic IR [157,158]. Interestingly, the latter improvement was correlated with a reduction in steatosis [158]. On closer examination however, metabolic and histological improvement do not always coincide $[158,160]$. For example, although virtually all patients (93\%) experiencing a significant reduction in steatosis also had a reduction in HOMA score, this was also the case for a large proportion (59\%) of patients with unchanged steatosis [158]. Moreover, a subsequent analysis found that even a strong reduction in HOMA levels does not predict an improvement in necroinflammation or fibrosis. This "dissociation" between the improvement of IR and unchanged liver histology has led our group to speculate that IR occurs very early in the pathogenesis of
NAFLD and thus is a factor "necessary but not sufficient" for the development of liver disease [85].

\section{Biochemical Response}

Glitazones reduce aminotransferases levels [157,158]. ALT levels decline at week 4 and this effect is maintained during treatment. However, treatment longer than one year might not result in any further improvements [84,160].

\section{Histological Response \\ $\underline{\text { Steatosis }}$}

Most trials show a reduction in steatosis compared to placebo, with a variable individual response ranging from $47 \%$ to $65 \%$ $[157,158,160,162]$. Only a single trial showed no difference between groups, perhaps because the patients had minimal steatosis $(5-25 \%)$ at baseline, making differences between groups harder to discern [159].

\section{Necroinflammation and Fibrosis}

In published studies, assessment of inflammation is complicated by the differing histological scoring systems used. Ballooning improved in $32-54 \%$ of patients, significantly more than placebo in two RCTs $[157,159]$. Likewise, in the PIVENS study, the change in ballooning was higher with Pioglitazone than placebo [160]. Intralobular inflammation improved in all studies [157,159-161] but one [158]. Portal inflammation was unchanged or worsened with rosiglitazone [162].

Not all studies reported on changes in the NAFLD activity score (NAS). In a 6 month study, the score improved in $46 \%$ of patients treated with pioglitazone versus only $14 \%$ of the placebo 
group ( $\mathrm{p}=0.02$ ). This could have been due to a reduction in steatosis which is part of the score. In contrast, a 1-year study with rosiglitazone failed to demonstrate any significant changes in the NAS score $[157,158]$, whereas a 2-year study with pioglitazone improved the NAS score significantly more than placebo [160] .

Even after prolonged treatment with rosiglitazone, fibrosis was not altered [84], including when assessed by micromorphometry, a more reliable quantitative technique $[157,159,161]$.

\section{C). TZDs and HCC and Non-hepatic Cancer}

Peroxisome-proliferator-activated receptor gamma (PPAR $\gamma$ ) plays a role in the development of some malignancies, including HCC [101,163]. In vitro and in vivo models indicate that the inhibition of PPAR $\gamma$ is able to inhibit HCC cell proliferation and tumor growth by inducing cell cycle arrest and apoptosis via the regulation of a panel of downstream effector molecules [164,165]. PPAR $\gamma$ inhibition also induces an inhibitory effect on HCC metastasis [166]. Therefore, PPAR $\gamma$ inhibition obtained through administration of TZDs could be anti-tumorigenic [167]. (Table 3) [30,100, $101,165,168-171]$

\section{D). Adverse Effects of TZDs and their use in CVD}

TZDs are nuclear receptor ligands and have several biological effects [172] including unwanted effects such as an increased risk of vascular events, precipitation or worsening of congestive heart failure, osteoporosis, weight gain, and bladder cancer. Increased cardiovascular risk appears to be drug-specific rather than a class effect. Further studies are required to evaluate the effectiveness and safety of glitazones for the treatment of NAFLD associated with either impaired glucose tolerance or overt type 2 diabetes mellitus. [174].

\section{Rosiglitazone and Pioglitazone Vascular Disease}

Atherosclerosis is one of the major complication of type 2 diabetes mellitus and NASH and the ideal ISD should protect these patients from excess cardiovascular risk $[174,175]$. Concerns remain as to whether rosiglitazone increases cardiovascular risks, but it is also clear that this drug does not substantially reduce these risks, a benefit that would be highly desirable during treatment of NAFLD alone or in associated with type 2 diabetes mellitus.

Unlike rosiglitazone, pioglitazone has not been associated with excess cardiovascular morbility and mortality, as demonstrated by the prospective, placebo-controlled PROactive trial [176,177].

\section{Congestive Heart Failure}

TZDs have been associated with an increased risk of congestive heart failure. The absolute risk, however, is small, amounting to $0.5 \%$ compared to $0.1 \%$ for placebo in the DREAM trial of rosiglitazone [178], 6\% compared to $4 \%$ in the PROactive trial [176] of pioglitazone, and a doubling of relative risk upon meta-analysis [179]. Longer duration of use, age over 50, and obesity are predictive factors for developing congestive heart failure [177].

\section{Bone Loss and Fractures}

Schwartz et al showed that in patients with type 2 diabetes mellitus, TZDs use was associated with accelerated bone loss in women but not men [180]. Furthermore post-hoc analyses for fractures of industry-sponsored trial data confirms that rosiglitazone is associated with a doubling of the bone fracture rate in women, mostly in the arms, hands, and feet. Pioglitazone was similarly associated with increased fractures in the distal arm and legs. The mechanism is thought to relate to interference of bone formation and turnover by TZDs.

\section{Weight Gain}

TZDs induce in some but not all patients, a weight gain of $\sim 4$ $\mathrm{kg}[158,162,176]$. This effect is due to expanded peripheral rather than visceral adipose tissue and thus does not increase the metabolic and inflammatory abnormalities associated with intra- abdominal adiposity [181] but rather mirrors redistribution of fat to "where it belongs" and is compounded by concurrent fluid retention [182,183].

In conclusion, TZDs modestly improve histological parameters in NAFLD, but induce weight gain and so further studies are needed to demonstrate the long term beneficial effects of these drugs for routine use in the prevention and therapy of NAFLD [184]. TZDs prevent the development type 2 diabetes mellitus and seem to be suitable for use in the subgroup of subjects with impaired glucose tolerance and no heart failure $[178,185]$.

\section{SECTION 4. NAFLD AND INSULIN SENSITIZERS IN CHILDHOOD}

As a result of the overweight and obesity epidemic, NAFLD is the most common cause of chronic liver disease and a leading cause of liver transplantation in children and teen agers in the United States [186,187]. NAFLD in children has a different histological spectrum, but as in adults, can evolve to cirrhosis and is associated with increased cardiovascular risk [188-173].

As in adults, therapeutic approaches in children are directed to reduce IR but, to date, there are no proven therapies that halt progression or improve prognosis [58,193]. ISDs such as metformin and TZDs have been used, although their long-term efficacy and safety remain unknown [194]. The TONIC trial was a double blind, multicenter randomized trial evaluating NAFLD treatment using histologic outcomes. It involved 173 children aged 8 to 17 years randomized to receive either metformin, Vitamin $\mathrm{E}$ or placebo [195]. In the subgroup treated with metformin, improvements in ALT and hepatocellular ballooning were detected compared to the placebo group, although no significant changes were demonstrated in steatosis, inflammation or the NAS score over a 96 week followup. Lifestyle changes aiming to reduce obesity have proven effective in all age groups and therefore should be adopted [196,197].

\section{SECTION 5. INSULIN SENSITIZERS BEYOND MET- FORMIN AND THIAZOLIDINEDIONES: WHAT'S NEXT?}

Other ISDs that are potentially useful in human NASH are being developed or tested.

Recent studies have shown a direct and beneficial effect on hepatocytes of glucagon-like peptide-1 (GLP-1), a class of drugs used for the treatment of type 2 diabetes mellitus. GLP-1, acts by activating genes involved in $\beta$-oxidation of fatty acids and insulinsensitization [198,199]. In terms of clinical use exenatide, a synthetic version of exendin-4, a hormone initially isolated from the saliva of the Gila monster was approved by the FDA for use in the US in 2005 as an adjunctive therapy for type 2 diabetes mellitus and is available as a subcutaneous injection. This peptide is a GLP1 receptor agonist and primarily stimulates the release of insulin from pancreatic $\beta$-cells. However, exenatide does not act as a direct insulin sensitizer, but rather induces clinically significant weight loss, which may eventually lead to an insulin-sensitizing effect. In ob/ob mice, exendin-4 significantly reduced blood glucose, improved IS, and reduced hepatic steatosis[200]. GLP-1 proteins have a novel direct effect on hepatocyte fat metabolism [201].

An open-label, uncontrolled clinical trial using exenatide to assess drug safety in diabetics over a period of $\sim 3.5$ years revealed that patients had improved AST and insulin sensitivity [202]. In addition, those with elevated ALT at baseline $(n=116)$ had significant reductions in ALT, while $41 \%$ achieved normal levels on treatment. Patients with elevated ALT compared to those with normal ALT levels at baseline tended to lose more weight. However, weight change was not correlated with baseline ALT values nor were changes in ALT. There is one case report of a 59-year-old male with type 2 diabetes mellitus who was treated with exenatide and metformin [203]. Following a 44- week course of exenatide, this patient displayed normalized ALT, and spectroscopic evidence of decreased hepatic steatosis (from $15.8 \%$ to $4.3 \%$ ). 
Table 3. Insulin sensitizers and prevention of hepatocellular carcinoma

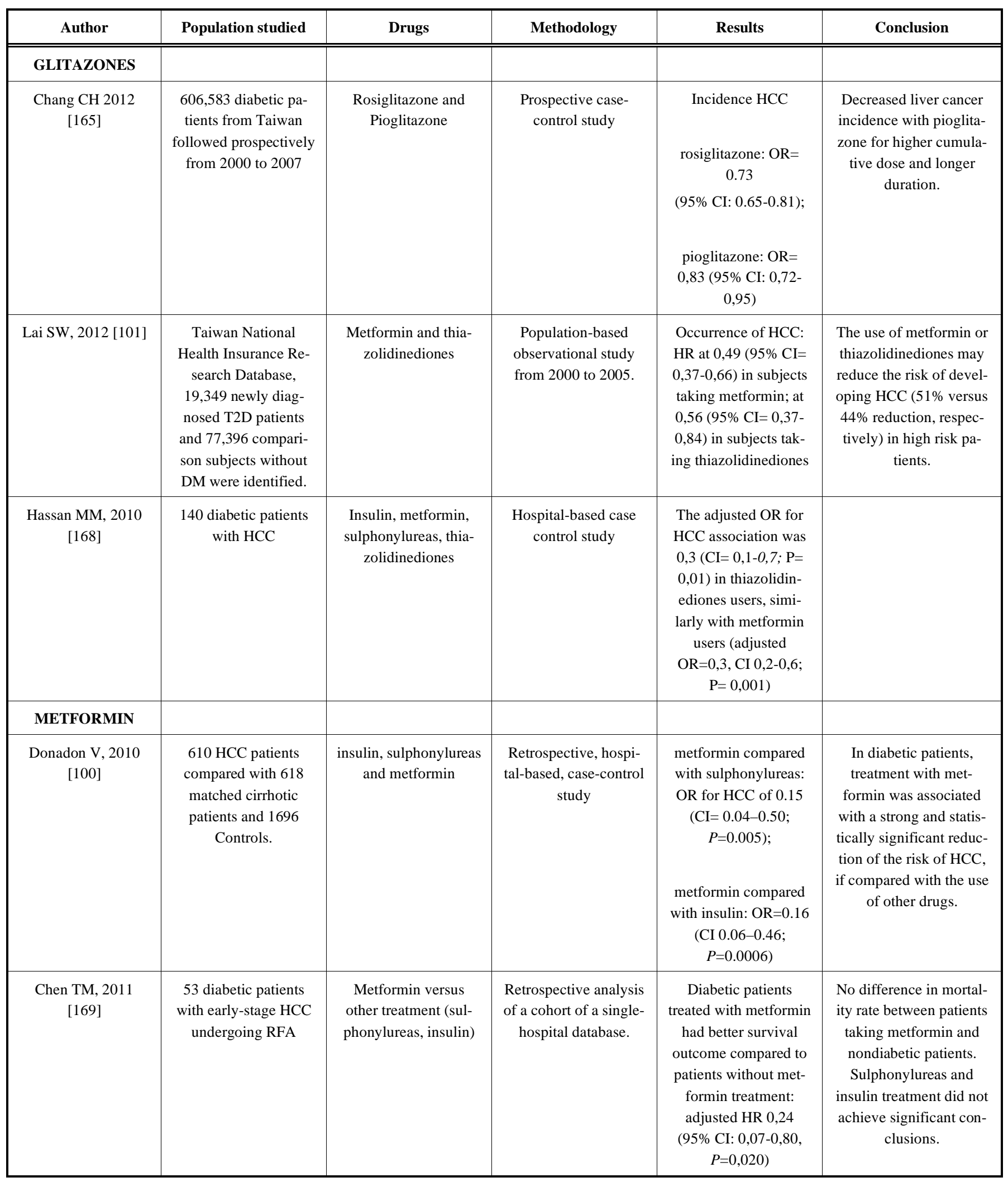


(Table 3) Contd....

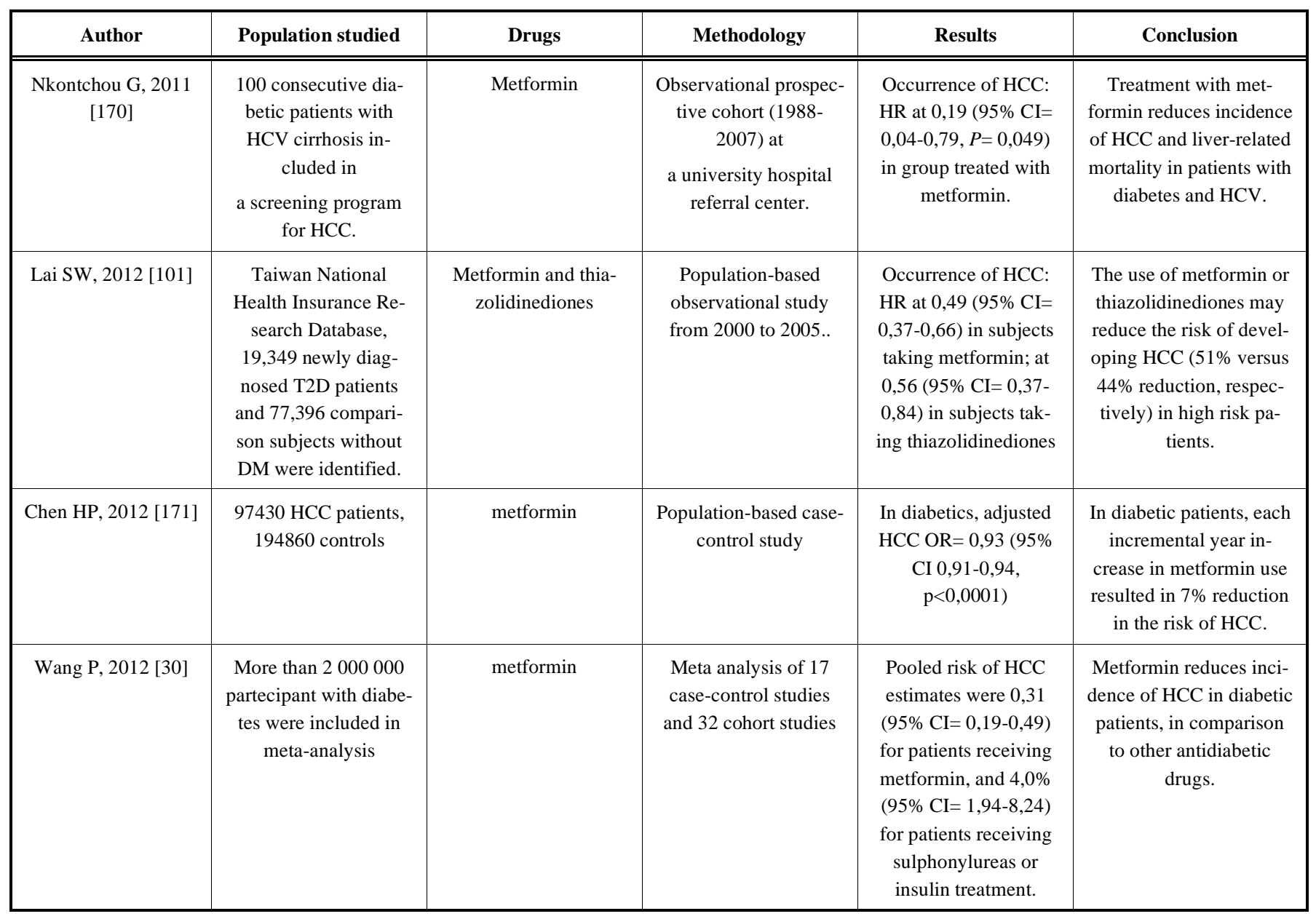

The long-acting glucagon-like peptide liraglutide also improves insulin sensitivity and reduces lipid accumulation in liver through multiple and incompletely understood mechanisms [204, 205].

Liraglutide, has $97 \%$ amino acid sequence identity to native human GLP-1 and an acyl side-chain attachment, which makes it bind to albumin. These small structural differences prolong the half-life of GLP-1 to 13 hours, making it possible to administer daily. Several studies showed that liraglutide was well tolerated, improved glycaemic control with a low risk of hypoglycemia, improved beta-cell function, and was associated with weight reduction. The receptors of GLP-1 analogues also exist in human hepatocytes and administration of GLP-1 analogues are reported to directly reduce liver steatosis and fibrosis in vivo [201,206]. More studies are underway to ascertain its effect in NAFLD/NASH[207].

Similarly, the dipeptidyl peptidase-IV inhibitor (DPP-IV) sitagliptin improves postprandial insulin secretion, reduces excess glucagon secretion, promote saxiety, ameliorates liver tests in T2D and affects liver fibrogenesis either via increasing GLP-1 activity and/or anti-inflammatory activities in liver [208-211]. In a recent openlabel, single-arm observational pilot study, treatment with sitagliptin (100 mg once a day per 12 months) ameliorated liver enzymes and hepatocyte ballooning in NASH patients with type 2 diabetes mellitus [212].

Other PPAR agonists have been shown to have insulinsensitizing effects and thus are potentially indicated for use in NAFLD. These include the PPAR- $\delta$ agonist GW501516 which has been examined in a mouse model of NASH [213]. GW501516 reduced hepatic triglyceride, hepatic fat droplets, inflammatory cells, and decreased the expression of pro-inflammatory markers. Likewise, PPAR- $\delta$ agonist treatment in an ethanol-mediated hepatic injury and steatosis rat model attenuated the severity of adverse effects from ethanol on hepatic repair by restoring insulin responsiveness [214]. Collectively, these findings suggest that PPAR- $\delta$ is a potential therapeutic target for IR and hepatic steatosis [215,216].

Finally, there was initial promise with the cannabinoid type I (CB1) receptor blockers in improving hepatic steatosis and promoting weight loss in NAFLD. The endocannabinoid system is involved in the regulation of food uptake, body weight, and insulin sensitivity. Obesity leads to up-regulation of the CB1 receptors, which leads to hepatic lipogenesis, fatty acid synthesis in adipocytes, and decreased adiponectin levels [217]. In two large, placebo-controlled clinical trials using the $\mathrm{CB} 1$ antagonist rimonabant to study weight loss, metabolic improvements were remarkable with notable improvements in insulin sensitivity [218,219]. This was largely thought to be due to weight loss, but the metabolic effects appear to exceed what is directly related to weight loss alone, suggesting a direct action in improving insulin sensitivity. While there were several CB1 antagonists in development (Rimonabant (SR141716), taranabant, and otenabant), enthusiasm for these agents has waned after Rimonabant, was withdrawn from the market in the European Union due to adverse psychiatric effects, mostly severe depression, and suicidal behavior [220]. Current research is devoted to developing peripherally selective CBI antagonists devoid of the psychiatric adverse effects. 
Table 4. Comparison of the Effectiveness of the Various Insulin Sensitizers in NASH

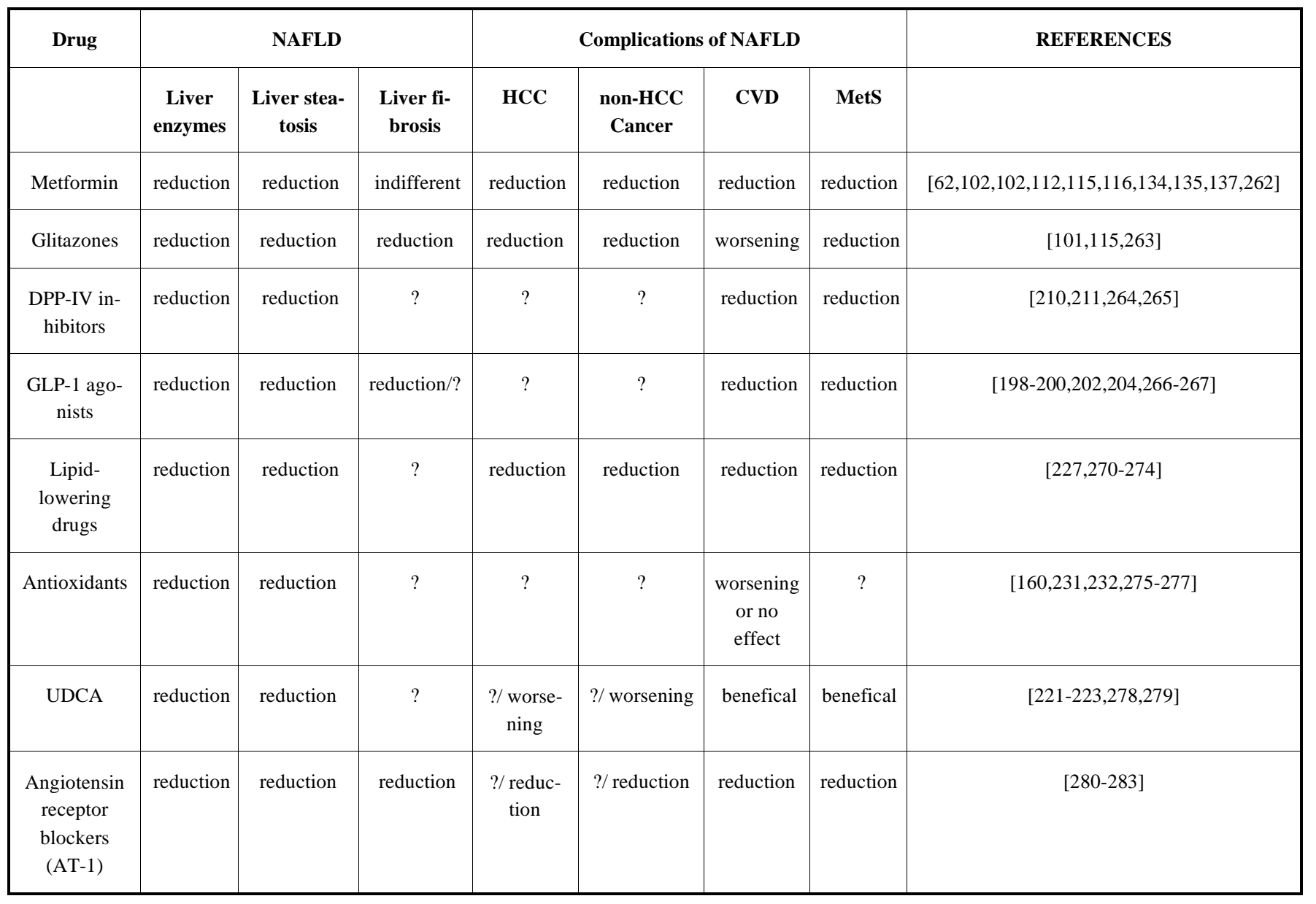

Legend: NAFLD= nonalcoholic fatty liver disease; $\mathrm{HCC}=$ hepatocellular carcinoma $\mathrm{CVD}=$ cardiovascular disease; MetS= Metabolic Syndrome; DPP-IV= dipeptidyl peptidase IV; GLP-1= glucagon-like peptide 1; UDCA= Ursodeoxycholic acid; Antioxydant= Vitamin E, betaine, N-acetyl-cysteine; Lipid-lowering drugs= statins, fibrates, niacin, ezetimibe, n-3 polyunsaturated fatty acids (PUFAs).

"?"= undetermined effect.

Impaired regulation of bile acid metabolism may contribute to the development of NAFLD. Ursodeoxycholic acid (UDCA) improves hepatic metabolism and insulin sensitivity by multiple effects including the regulation of de novo lipogenesis, stimulation of glucagon-like peptide-1 secretion in the small intestine, and improved energy homeostasis in brown adipose issue and skeletal muscle [221,222]. However clinical trials of these agents in NASH have provided negative results and bile acids are not recommended [223].

Statins have immunomodulatory and anti-inflammatory actions, useful in the treatment of both CVD and NASH [224-229]. Individual statins such as rosuvastatin have been shown to exert a beneficial effect in improving insulin sensitivity in animal models of NAFLD [230]. However there are no sufficiently powered studies to demonstrate a beneficial effect of these agents on liver histology in human NAFLD/NASH.

Oxidative stress induced by lipid peroxidation and the production of reactive oxygen species (ROS) are key-mechanisms for the development of NASH and cardiovascular disease. Antioxidant agents (including Vitamin $\mathrm{E}$, betaine and $\mathrm{N}$-acetyl-cysteine) may therefore be effective in treating NASH and improve liver enzymes and histology as recently demonstrated by the PIVENS trial [160]. However, the data need to be replicated in well-designed randomized controlled trials that are adequately powered and of a sufficient duration to determine clear efficacy [160,231,232].
Adiponectin is an adipocytokine with pleiotropic effects acting principally through AMPK pathway activation [233-235] including a reduction in the formation of vascular plaques, improving insulin sensitivity and glucose control, and anti-inflammatory and antifibrogenic actions in the liver which results in protective effects against HCC [236-240].

Adiponectin is a hepatic insulin sensitizer and inhibitor of tumor necrosis factor, and in NAFLD, low adiponectin levels are associated with reduced steatosis and inflammation [241-243]. Conversely, elevated serum concentrations of adiponectin are associated with protective effects against hepatic steatosis $[60,244$, 245]. Thus, adiponectin agonists may be beneficial for the treatment of NAFLD in future.

Estrogens - Interestingly, estrogens may be considered as ISDs [246-248]. Estrogen receptors (ER) are expressed in many tissues including the liver and white adipose tissue, and estrogens act via nuclear and extranuclear pathways [249,250]. Estrogens stimulates leptin synthesis and secretion via ER-dependent transcriptional mechanisms, leading to metabolic regulation [251]. The finding that human NAFLD demonstrates sexual dimorphism in its manifestations [252-254], that treatment with the antiestrogen tamoxifen [255] and naturally occurring hyperandrogenism in PCOS [256] are associated with NASH and that hormonal replacement therapy is associated with antifibrotic activity in women with chronic hepatitis C [257] and that estrogens exert hepatoprotective effects in vitro 
[258], all suggest that estrogens may have a role in the management of NAFLD. However, no clinical data are available in this regard.

\section{CONCLUSIONS}

Suggestions for the use of the most relevant ISDs in clinical practice have been detailed in conclusions to Section 2 and Section 3. Certain agents such as metformin and thiazolidinediones might be appropriate for early stage disease (i.e. pure steatosis). In cases of NASH/cirrhosis, particularly in those with decompensated liver disease, metformin should be used with caution. The strong pathogenic association of IR with NAFLD justifies further consideration of the use of ISDs. Available data suggest that the pathogenesis of liver injury in this disease is multi factorial [259] and clinical trials of a combined therapeutic approach including various ISDs classes needs to be considered. [260,261].

Finally, fully innovative research avenues are disclosed by the finding that other novel "non-classic" insulin sensitizers may be of potential utility in the prevention and treatment of NAFLD and its metabolic, hepatic and extrahepatic vascular and oncologic complications (Table 4). [62,101,102,111,115,116,134,135,137,160,198$200,202,204,210,211,221-223,227,231,232,262-283]$

\section{CONFLICT OF INTEREST}

The authors confirm that this article content has no conflicts of interest.

\section{ACKNOWLEDGEMENTS}

Jacob George and Lionel Hebbard are supported by the Robert W. Storr Bequest to the Sydney Medical Foundation and grants from the National Health and Medical Research Council of Australia.

Paola Loria and Lucia Carulli are supported by funds from European Community's Seventh Framework Programme (FP7/2007-2013) under grant agreement no. HEALTH-F2-2009241762 for the FLIP project and funds "regionali" PRIER (Program 2008-2012).

We would like to thank to Amedeo Lonardo for his precious contribution and assistance in the revision of the manuscript

\section{ABBREVIATIONS}

$\begin{array}{lll}\text { ALT } & = & \text { Alanine aminotransferase } \\ \text { CHD } & = & \text { Coronary heart disease } \\ \text { CVD } & = & \text { Cardiovascular disease } \\ \text { DPP-IV } & = & \text { Dipeptidyl peptidase-IV inhibitors } \\ \text { GLP-1 } & = & \text { Glucagon-like peptide-1 } \\ \text { HCC } & = & \text { Hepatocellular carcinoma } \\ \text { IR } & = & \text { Insulin Resistance } \\ \text { ISDs } & = & \text { Insulin-sensitizer drugs } \\ \text { MetS } & = & \text { Metabolic Syndrome } \\ \text { NAFLD } & = & \text { Nonalcoholic fatty liver disease } \\ \text { NAS } & = & \text { NAFLD score } \\ \text { NASH } & = & \text { Nonalcoholic steatohepatitis } \\ \text { PCOS } & = & \text { Polycystic ovary syndrome } \\ \text { T2D } & = & \text { Type } 2 \text { diabetes mellitus } \\ \text { TZDs } & = & \text { Thiazolidinediones } \\ \text { TGs } & = & \text { Triglycerides } \\ \text { UDCA } & = & \text { Ursodeoxycholic acid }\end{array}$

\section{REFERENCES}

[1] Torres DM, Williams CD, Harrison SA. Features, Diagnosis, and Treatment of Nonalcoholic Fatty Liver Disease. Clin Gastroenterol Hepatol 2012
Loria P, Adinolfi LE, Bellentani S, et al. NAFLD Expert Committee of the Associazione Italiana per lo studio del Fegato. Practice guidelines for the diagnosis and management of nonalcoholic fatty liver disease. A decalogue from the Italian Association for the Study of the Liver (AISF) Expert Committee. Dig Liver Dis 2010; 42: 272-82.

[3] Radu C, Grigorescu M, Crisan D, Lupsor M, Constantin D, Dina L. Prevalence and associated risk factors of non-alcoholic fatty liver disease in hospitalized patients. J Gastrointestin Liver Dis 2008; 17: 255-60

[4] Vernon G, Baranova A, Younossi ZM. Systematic review: the epidemiology and natural history of non-alcoholic fatty liver disease and nonalcoholic steatohepatitis in adults. Aliment Pharmacol Ther 2011; 34: 274-85.

[5] Browning JD, Szczepaniak LS, Dobbins R, et al. Prevalence of hepatic steatosis in an urban population in the United States: impact of ethnicity. Hepatology 2004; 40: 1387-95.

[6] Bambha K, Belt P, Abraham M, et al. Nonalcoholic Steatohepatitis Clinical Research Network Research Group. Ethnicity and nonalcoholic fatty liver disease. Hepatology 2012; 55: 769-80.

[7] Bugianesi E, McCullough AJ, Marchesini G. Insulin resistance: a metabolic pathway to chronic liver disease. Hepatology 2005; 42 987-1000.

[8] Vuppalanchi R, Chalasani N. Nonalcoholic fatty liver disease and nonalcoholic steatohepatitis: Selected practical issues in their evaluation and management. Hepatology 2009; 49: 306-17.

[9] Kim HJ, Kim HJ, Lee KE, et al. Metabolic significance of nonalcoholic fatty liver disease in nonobese, nondiabetic adults. Arch Intern Med 2004; 164: 2169-75.

[10] Musso G, Gambino R, Cassader M, Pagano G. Meta-analysis: natural history of non-alcoholic fatty liver disease (NAFLD) and diagnostic accuracy of non-invasive tests for liver disease severity. Ann Med 2011; 43: 617-49.

[11] Brunt EM, Janney CG, Di Bisceglie AM, Neuschwander-Tetri BA Bacon BR. Nonalcoholic steatohepatitis: a proposal for grading and staging the histological lesions. Am J Gastroenterol. 1999; 94: 2467-74.

[12] Matteoni CA, Younossi ZM, Gramlich T, Boparai N, Liu YC, McCullough AJ. Nonalcoholic fatty liver disease: a spectrum of clinical and pathological severity. Gastroenterology. 1999; 116: 1413-9.

[13] Loria P, Lonardo A, Targher G. Is liver fat detrimental to vessels?: intersections in the pathogenesis of NAFLD and atherosclerosis. Clin Sci (Lond) 2008; 115: 1-12

[14] Lonardo A, Loria P. Insulin resistance, Type 2 Diabetes and Chronic Liver disease. A deadly trio. Clinical Medicine: Endocrinology and Diabetes 2009; 2: 81-88.

[15] Wieckowska A, Feldstein AE. Diagnosis of nonalcoholic fatty liver disease: invasive versus noninvasive. Semin Liver Dis 2008; 28 : 386-95.

[16] Bullock RE, Zaitoun AM, Aithal GP, Ryder SD, Beckingham IJ, Lobo DN. Association of non-alcoholic steatohepatitis without significant fibrosis with hepatocellular carcinoma. J Hepatol 2004; 41: 685-6.

[17] Bugianesi E. Non-alcoholic steatohepatitis and cancer. Clin Liver Dis 2007; 11: 191-207.

[18] Hashimoto E, Yatsuji S, Tobari M, et al Hepatocellular carcinoma in patients with nonalcoholic steatohepatitis. J Gastroenterol 2009 44: 89-95.

[19] Adams LA, Lymp JF, St Sauver J, et al The natural history of nonalcoholic fatty liver disease: a population-based cohort study. Gastroenterology 2005; 129: 113-21.

[20] Deleuran T, Grønbaek H, Vilstrup H, Jepsen P. Cirrhosis and mortality risks of biopsy-verified alcoholic pure steatosis and steatohepatitis: a nationwide registry-based study. Aliment Pharmacol Ther 2012; 35: 1336-42.

[21] Powell EE, Cooksley WG, Hanson R, Searle J, Halliday JW, Powell LW. The natural history of nonalcoholic steatohepatitis: a follow-up study of forty-two patients for up to 21 years. Hepatology. 1990; 11: 74-80.

[22] Williams CD, Stengel J, Asike MI, et al. Prevalence of nonalcoholic fatty liver disease and nonalcoholic steatohepatitis among a largely middle-aged population utilizing ultrasound and liver biopsy: a prospective study. Gastroenterology 2011; 140: 124-31 
[23] El-Serag HB, Hampel H, Javadi F. The association between diabetes and hepatocellular carcinoma: a systematic review of epidemiologic evidence. Clin Gastroenterol Hepatol 2006; 4: 369-80.

[24] Davila JA, Morgan RO, Shaib Y, McGlynn KA, El-Serag HB. Diabetes increases the risk of hepatocellular carcinoma in the United States: a population based case control study. Gut 2005; 54: 533-9.

[25] El-Serag HB. Hepatocellular carcinoma: recent trends in the United States. Gastroenterology 2004; 127: S27-34.

[26] Chen CL, Yang HI, Yang WS. Metabolic factors and risk of hepatocellular carcinoma by chronic hepatitis B/C infection: a follow-up study in Taiwan. Gastroenterology 2008; 135: 111-21.

[27] Hassan MM, Hwang LY, Hatten CJ, et al. Risk factors for hepatocellular carcinoma: synergism of alcohol with viral hepatitis and diabetes mellitus. Hepatology 2002; 36: 1206-13

[28] Veldt BJ, Chen W, Heathcote EJ, et al. Increased risk of hepatocellular carcinoma among patients with hepatitis $\mathrm{C}$ cirrhosis and diabetes mellitus. Hepatology 2008; 47: 1856-62.

[29] Wang CS, Yao WJ, Chang TT, Wang ST, Chou P. The impact of type 2 diabetes on the development of hepatocellular carcinoma in different viral hepatitis statuses. Cancer Epidemiol Biomarkers Prev 2009; 18: 2054-60.

[30] Wang P, Kang D, Cao W, Wang Y, Liu Z. Diabetes mellitus and risk of hepatocellular carcinoma: a systematic review and metaanalysis. Diabetes Metab Res Rev 2012; 28: 109-22.

[31] Nzeako UC, Goodman ZD, Ishak KG. Hepatocellular carcinoma in cirrhotic and noncirrhotic livers. A clinico-histopathologic study of 804 North American patients. Am J Clin Pathol. 1996; 105: 65-75.

[32] Brancatelli G, Federle MP, Grazioli L, Carr BI. Hepatocellular carcinoma in noncirrhotic liver: CT, clinical, and pathologic findings in 39 U.S. residents. Radiology 2002; 222: 89-94.

[33] Baffy G. Editorial: hepatocellular carcinoma in type 2 diabetes: more than meets the eye. Am J Gastroenterol 2012; 107: 53-5.

[34] Sanyal A, Poklepovic A, Moyneur E, Barghout V. Populationbased risk factors and resource utilization for HCC: US perspective. Curr Med Res Opin 2010; 26: 2183-91.

[35] Starley BQ, Calcagno CJ, Harrison SA. Nonalcoholic fatty liver disease and hepatocellular carcinoma: a weighty connection. Hepatology 2010; 51: 1820-32.

[36] Lonardo A, Caldwell SH, Loria P. Clinical Physiology of NAFLD: a critical overview of pathogenesis and treatment. Expert Rev Endocrinol Metab 2010; 5: 403-423.

[37] Wanless IR, Bargman JM, Oreopoulos DG, Vas SI. Subcapsular steatonecrosis in response to peritoneal insulin delivery: a clue to the pathogenesis of steatonecrosis in obesity. Mod Pathol 1989; 2: 69-74.

[38] Sanyal AJ; American Gastroenterological Association. AGA technical review on nonalcoholic fatty liver disease. Gastroenterology 2002; 123: 1705-25.

[39] Torun D, Oguzkurt L, Sezer S, et al. Hepatic subcapsular steatosis as a complication associated with intraperitoneal insulin treatment in diabetic peritoneal dialysis patients. Perit Dial Int 2005; 25: 596600 .

[40] Samuel VT, Shulman GI. Mechanisms for insulin resistance: common threads and missing links. Cell 2012. 148: 852-71.

[41] Targher G, Bertolini L, Rodella S, et al. NASH predicts plasma inflammatory biomarkers independently of visceral fat in men. Obesity (Silver Spring) 2008; 16: 1394-9

[42] Rhee EJ, Lee WY, Cho YK, Kim BI, Sung KC. Hyperinsulinemia and the development of nonalcoholic Fatty liver disease in nondiabetic adults. Am J Med 2011; 124: 69-76.

[43] Cusi K. Role of obesity and lipotoxicity in the development of nonalcoholic steatohepatitis: pathophysiology and clinical implications. Gastroenterology 2012; 142: 711-25.

[44] Kersten S, Desvergne B, Wahli W. Roles of PPARs in health and disease. Nature 2000; 405: 421-4.

[45] Lam TK, Carpentier A, Lewis GF, van de Werve G, Fantus IG, Giacca A. Mechanisms of the free fatty acid-induced increase in hepatic glucose production. Am J Physiol Endocrinol Metab 2003; 284: E863-73.

[46] Roden M, Price TB, Perseghin G, et al. Mechanism of free fatty acid-induced insulin resistance in humans. J Clin Invest. 1996; 97 : 2859-65

[47] Loria P, Carulli L, Bertolotti M, Lonardo A. Endocrine and liver interaction: the role af endocrine pathways in NASH. Nat Rev Gastroenterol Hepatol 2009; 6: 236-47.
[48] Reaven G. Insulin resistance and coronary heart disease in nondiabetic individuals. Arterioscler Thromb Vasc Biol 2012; 32: 1754-9

[49] Nikolopoulou A, Kadoglou NP. Obesity and metabolic syndrome as related to cardiovascular disease. Expert Rev Cardiovasc Ther 2012; 10: 933-9.

[50] Chitturi S, Abeygunasekera S, Farrell GC, et al. NASH and insulin resistance: Insulin hypersecretion and specific association with the insulin resistance syndrome. Hepatology 2002; 35: 373-9.

[51] Lonardo A, Lombardini S, Ricchi M, Scaglioni F, Loria P. Review article: hepatic steatosis and insulin resistance. Aliment Pharmacol Ther 2005; 22: 64-70.

[52] Utzschneider KM, Kahn SE. Review: The role of insulin resistance in nonalcoholic fatty liver disease. J Clin Endocrinol Metab 2006; 91: 4753-61.

[53] Maurantonio M, Ballestri S, Odoardi MR, Lonardo A, Loria P. Treatment of atherogenic liver based on the pathogenesis of nonalcoholic fatty liver disease: a novel approach to reduce cardiovascular risk? Arch Med Res 2011; 42: 337-53.

[54] Gastaldelli A, Kozakova M, Hojlund K, et al. RISC Investigators. Fatty liver is associated with insulin resistance, risk of coronary heart disease, and early atherosclerosis in a large European population. Hepatology 2009; 49: 1537-44.

[55] Day CP, James OF. Steatohepatitis: a tale of two "hits"? Gastroenterology. 1998; 114: 842-5.

[56] Feldstein AE, Werneburg NW, Canbay A, et al. Free fatty acids promote hepatic lipotoxicity by stimulating TNF-alpha expression via a lysosomal pathway. Hepatology 2004; 40: 185-94

[57] Diehl AM. Tumor necrosis factor and its potential role in insulin resistance and nonalcoholic fatty liver disease. Clin Liver Dis 2004 8: 619-38.

[58] Ibrahim SH, Kohli R, Gores GJ. Mechanisms of lipotoxicity in NAFLD and clinical implications. J Pediatr Gastroenterol Nutr 2011; 53: 131-40.

[59] Marchesini G, Brizi M, Morselli-Labate AM, et al. Association of nonalcoholic fatty liver disease with insulin resistance. Am J Med. 1999; 107: 450-5.

[60] Hui JM, Hodge A, Farrell GC, Kench JG, Kriketos A, George J. Beyond insulin resistance in NASH: TNF-alpha or adiponectin? Hepatology 2004; 40: 46-54.

[61] Bugianesi E, Moscatiello S, Ciaravella MF, Marchesini G. Insulin resistance in nonalcoholic fatty liver disease. Curr Pharm Des 2010; 16: 1941-51

[62] Gallagher EJ, LeRoith D. Minireview: IGF, insulin and cancer. Endocrinology 2011; 152: 2546-51.

[63] Pollak M. The insulin and insulin-like growth factor receptor family in neoplasia: an update. Nat Rev Cancer 2012; 12: 159-69.

[64] Ullrich A, Bell JR, Chen EY, et al. Human insulin receptor and its relationship to the tyrosine kinase family of oncogenes. Nature. 1985; 313: 756-61

[65] Belfiore A, Frasca F, Pandini G, Sciacca L, Vigneri R. Insulin receptor isoforms and insulin receptor/insulin-like growth factor receptor hybrids in physiology and disease. Endocr Rev 2009; 30 : 586-623

[66] Calle EE, Rodriguez C, Walker-Thurmond K, Thun MJ. Overweight, obesity, and mortality from cancer in a prospectively studied cohort of U.S. adults. N Engl J Med 2003; 348: 1625-38.

[67] Caldwell SH, Crespo DM, Kang HS, Al-Osaimi AM. Obesity and hepatocellular carcinoma. Gastroenterology 2004; 127: S97-103.

[68] Park EJ, Lee JH, Yu GY, et al. Dietary and genetic obesity promote liver inflammation and tumorigenesis by enhancing IL-6 and TNF expression. Cell 2010; 140: 197-208.

[69] Algire C, Amrein L, Bazile M, David S, Zakikhani M, Pollak M. Diet and tumor LKB1 expression interact to determine sensitivity to anti-neoplastic effects of metformin in vivo. Oncogene 2011;30: 1174-82.

[70] Tanaka S, Mohr L, Schmidt EV, Sugimachi K, Wands JR. Biological effects of human insulin receptor substrate-1 overexpression in hepatocytes. Hepatology. 1997; 26: 598-604.

[71] Page JM, Harrison SA. NASH and HCC. Clin Liver Dis 2009; 13 631-47.

[72] Stepanova M, Younossi ZM. Independent Association Between Nonalcoholic Fatty Liver Disease and Cardiovascular Disease in the US Population. Clin Gastroenterol Hepatol 2012; 10: 646-50.

[73] Bhala N, Angulo P, van der Poorten D, et al. The natural history of nonalcoholic fatty liver disease with advanced fibrosis or cirrhosis: 
an international collaborative study. Hepatology 2011; 54: 120816.

[74] Shargorodsky M, Omelchenko E, Matas Z, Boaz M, Gavish D. Relation between augmentation index and adiponectin during oneyear metformin treatment for nonalcoholic steatohepatosis: effects beyond glucose lowering? Cardiovasc Diabetol 2012; 11: 61.

[75] Chavez-Tapia NC, Tellez-Avila FI, Barrientos-Gutierrez T, Mendez-Sanchez N, Lizardi-Cervera J, Uribe M. Bariatric surgery for non-alcoholic steatohepatitis in obese patients. Cochrane Database Syst Rev 2010; (1): CD007340.

[76] Westerink J, Visseren FL. Pharmacological and nonpharmacological interventions to influence adipose tissue function. Cardiovasc Diabetol 2011; 10: 13.

[77] Promrat K, Kleiner DE, Niemeier HM et al Randomized controlled trial testing the effects of weight loss on nonalcoholic steatohepatitis. Hematology.2010; 51: 121-9.

[78] Kistler K, Brunt EM, Clark JM et al Physical activity recommendations, exercise intensity, and histological severity of nonalcoholic fatty liver disease. Am J Gastroenterol 2011; 106: 460-8.

[79] Rabøl R, Falk Petersen K, Dufour S, Flannery C S, Shulman GL. Reversal of muscle insulin resistance with exercise reduces postprandial hepatic de novo lipogenesis in insulin resistant individuals. Proc Natl Acad Sci USA 2011; 108: 13705-9.

[80] de Luis DA, Aller R, Izaola O, Gonzalez Sagrato M, Conde R. Effect of two different hypocaloric diets in transaminases and insulin resistance in nonalcoholic fatty liver disease and obese patients. Nutr Hosp.2010; 25: 730-735.

[81] Chalasani N, Younossi Z, Lavine JE, et al. American Association for the Study of Liver Diseases; American College of Gastroenterology; American Gastroenterological Association. The diagnosis and management of non-alcoholic fatty liver disease: Practice guideline by the American Association for the Study of Liver Diseases, American College of Gastroenterology, and the American Gastroenterological Association. Am J Gastroenterol 2012; 107: 811-26.

[82] Mummadi RR, Kasturi KS, Chennareddygair S, Sood GK. Effect of bariatric surgery on nonalcoholic fatty liver disease: systematic review and meta-analysis. Clinical Gastro and Hepatol 2008; 6: 1396-402.

[83] Angelico F, Burattin M, Alessandri C, Del Ben M, Lirussi F. Drugs improving insulin resistance for non-alcoholic fatty liver disease and/or non-alcoholic steatohepatitis. Cochrane Database Syst Rev 2007; (1): CD005166.

[84] Ratziu V, Caldwell S, Neuschwander-Tetri BA. Therapeutic trials in nonalcoholic steatohepatitis: insulin sensitizers and related methodological issues. Hepatology 2010; 52: 2206-15.

[85] Lonardo A, Bellentani S, Ratziu V, Loria P. Insulin resistance in nonalcoholic steatohepatitis: necessary but not sufficient - death of a dogma from analysis of therapeutic studies ? Expert Rev Gastroenterol Hepatol 2011; 5: 279-89.

[86] Viollet B, Guigas B, Sanz Garcia N, Leclerc J, Foretz M, Andreelli F. Cellular and molecular mechanisms of metformin: an overview. Clin Sci (Lond) 2012; 122: 253-70.

[87] Viollet B, Guigas B, Leclerc J, et al. AMPactivated protein kinase in the regulation of hepatic energy metabolism: from physiology to therapeutic perspectives. Acta Physiol (Oxf) 2009; 196: 81-98.

[88] Gunton JE, Delhanty PJ, Takahashi S, Baxter RC. Metformin rapidly increases insulin receptor activation in human liver and signals preferentially through insulin-receptor substrate-2. J Clin Endocrinol Metab 2003; 88: 1323-32

[89] Maida A, Lamont BJ, Cao X, Drucker DJ. Metformin regulates the incretin receptor axis via a pathway dependent on peroxisome proliferator-activated receptor-alpha in mice. Diabetologia 2011; 54: 339-49

[90] Shu Y, Sheardown SA, Brown C, et al. Effect of genetic variation in the organic cation transporter 1 (OCT1) on metformin action. J Clin Invest 2007; 117: 1422-1431.

[91] Zhou G, Myers R, Li Y, et al. Role of AMP-activated protein kinase in mechanism of metformin action. J Clin Invest 2001; 108: 1167-74.

[92] Mazza A, Fruci B, Garinis GA, Giuliano S, Malaguarnera R, Belfiore A. The role of metformin in the management of NAFLD. Exp Diabetes Res 2012; 2012: 716404.

[93] Van Wagner LB, Rinella ME. The role of insulin-sensitizing agents in the treatment of nonalcoholic steatohepatitis. Therap Adv Gastroenterol 2011; 4: 249-63.
[94] 94González-Barroso MM, Anedda A, Gallardo-Vara E, RedondoHorcajo M, Rodríguez-Sánchez L, Rial E. Fatty acids revert the inhibition of respiration caused by the antidiabetic drug metformin to facilitate their mitochondrial $\beta$-oxidation. Biochim Biophys Acta 2012; 1817(10): 1768-75.

[95] Li Y, Xu S, Mihaylova MM, et al. AMPK phosphorylates and inhibits SREBP activity to attenuate hepatic steatosis and atherosclerosis in diet-induced insulin-resistant mice. Cell Metab 2011; 13: 376-88

[96] Kirpichnikov D, McFarlane SI, Sowers JR. Metformin: an update. Ann Intern Med 2002; 137: 25-33.

[97] Landin K, Tengborn L, Smith U. Treating insulin resistance in hypertension with metformin reduces both blood pressure and metabolic risk factors. J Intern Med. 1991; 229: 181-7.

[98] Evans JM, Donnelly LA, Emslie-Smith AM, Alessi DR, Morris AD. Metformin and reduced risk of cancer in diabetic patients. BMJ 2005; 330: 1304-5.

[99] Donadon V, Balbi M, Ghersetti M, et al. Antidiabetic therapy and increased risk of hepatocellular carcinoma in chronic liver disease. World J Gastroenterol 2009; 15: 2506-11.

[100] Donadon V, Balbi M, Mas MD, Casarin P, Zanette G. Metformin and reduced risk of hepatocellular carcinoma in diabetic patients with chronic liver disease. Liver Int 2010; 30: 750-8.

[101] Lai SW, Chen PC, Liao KF, Muo CH, Lin CC, Sung FC. Risk of hepatocellular carcinoma in diabetic patients and risk reduction associated with anti-diabetic therapy: a population-based cohort study. Am J Gastroenterol 2012; 107: 46-52.

[102] Marchesini G, Brizi M, Bianchi G, Tomassetti S, Zoli M, Melchionda N. Metformin in non-alcoholic steatohepatitis. Lancet 2001; 358: 893-4.

[103] Knowler WC, Barrett-Connor E, Fowler SE, et al. Diabetes Prevention Program Research Group. Reduction in the incidence of type 2 diabetes with lifestyle intervention or metformin. N Engl J Med 2002; 346: 393-403.

[104] Phielix E, Szendroedi J, Roden M. The role of metformin and thiazolidinediones in the regulation of hepatic glucose metabolism and its clinical impact. Trends Pharmacol Sci 2011; 32: 607-16.

[105] Mithieux G, Rajas F, Zitoun C. Glucose utilization is suppressed in the gut of insulin-resistant high fat-fed rats and is restored by metformin. Biochem Pharmacol 2006; 72: 1757-62

[106] Stumvoll M, Nurjhan N, Perriello G, Dailey G, Gerich JE. Metabolic effects of metformin in non-insulin-dependent diabetes mellitus. N Engl J Med. 1995; 333: 550-4.

[107] Musi N, Hirshman MF, Nygren J, et al. Metformin increases AMPactivated protein kinase activity in skeletal muscle of subjects with type 2 diabetes. Diabetes 2002; 51: 2074-81.

[108] Loomba R, Lutchman G, Kleiner DE, et al. Clinical trial: pilot study of metformin for the treatment of non-alcoholic steatohepatitis. Aliment Pharmacol Ther 2009; 29: 172-82.

[109] Wulffelé MG, Kooy A, de Zeeuw D, Stehouwer CD, Gansevoort RT. The effect of metformin on blood pressure, plasma cholesterol and triglycerides in type 2 diabetes mellitus: a systematic review. J Intern Med 2004; 256: 1-14.

[110] Goldberg RB, Temprosa M, Haffner S, et al. Diabetes Prevention Program Research Group. Effect of progression from impaired glucose tolerance to diabetes on cardiovascular risk factors and its amelioration by lifestyle and metformin intervention: the Diabetes Prevention Program randomized trial by the Diabetes Prevention Program Research Group. Diabetes Care 2009; 32: 726-32.

[111] Rakoski MO, Singal AG, Rogers MA, Conjeevaram H. Metaanalysis: insulin sensitizers for the treatment of non-alcoholic steatohepatitis. Aliment Pharmacol Ther 2010; 32: 1211-21.

[112] Musso G, Gambino R, Cassader M, Pagano G. A meta-analysis of randomized trials for the treatment of nonalcoholic fatty liver disease. Hepatology 2010; 52: 79-104.

[113] Bugianesi E, Gentilcore E, Manini R, et al. A randomized controlled trial of metformin versus vitamin $\mathrm{E}$ or prescriptive diet in nonalcoholic fatty liver disease. Am J Gastroenterol 2005; 100: 1082-90.

[114] Effect of intensive blood-glucose control with metformin on complications in overweight patients with type 2 diabetes (UKPDS 34) UK Prospective Diabetes Study (UKPDS) Group. Lancet. 1998; 352: 854-65. Erratum in: Lancet 1998; 352: 1558.

[115] Zarich SW. Does choice of antidiabetes therapy influence macrovascular outcomes? Curr Diab Rep 2010; 10: 24-31. 
[116] Sofer E, Boaz M, Matas Z, Mashavi M, Shargorodsky M. Treatment with insulin sensitizer metformin improves arterial properties, metabolic parameters, and liver function in patients with nonalcoholic fatty liver disease: a randomized, placebo-controlled trial. Metabolism 2011; 60: 1278-84.

[117] Nar A, Gedik O. The effect of metformin on leptin in obese patients with type 2 diabetes mellitus and nonalcoholic fatty liver disease. Acta Diabetol 2009; 46: 113-8.

[118] Tock L, Dâmaso AR, de Piano A, et al. Long-term effects of metformin and lifestyle modification on nonalcoholic Fatty liver disease obese adolescents. J Obes 2010; 2010.

[119] Cantrell LA, Zhou C, Mendivil A, Malloy KM, Gehrig PA, BaeJump VL. Metformin is a potent inhibitor of endometrial cancer cell proliferation--implications for a novel treatment strategy. Gynecol Oncol 2010; 116: 92-8.

[120] Gutierrez-Grobe Y, Ponciano-Rodríguez G, Ramos MH, Uribe M, Méndez-Sánchez N. Prevalence of non alcoholic fatty liver disease in premenopausal, posmenopausal and polycystic ovary syndrome women. The role of estrogens. Ann Hepatol 2010; 9: 402-9.

[121] de Oliveira CP, Stefano JT, de Siqueira ER, et al. Combination of $\mathrm{N}$-acetylcysteine and metformin improves histological steatosis and fibrosis in patients with non-alcoholic steatohepatitis. Hepatol Res 2008; 38: 159-65

[122] Idilman R, Mizrak D, Corapcioglu D, et al. Clinical trial: insulinsensitizing agents may reduce consequences of insulin resistance in individuals with non-alcoholic steatohepatitis. Aliment Pharmacol Ther 2008; 28: 200-8.

[123] Krakoff J, Clark JM, Crandall JP, et al. Diabetes Prevention Program Research Group. Effects of metformin and weight loss on serum alanine aminotransferase activity in the diabetes prevention program. Obesity (Silver Spring) 2010; 18: 1762-7.

[124] Garinis GA, Fruci B, Mazza A, et al. Metformin versus dietary treatment in nonalcoholic hepatic steatosis: a randomized study. Int J Obes (Lond) 2010; 34: 1255-64.

[125] Ou HY, Yang YC, Wu HT, Wu JS, Lu FH, Chang CJ. Serum fetuin-A concentrations are elevated in subjects with impaired glucose tolerance and newly diagnosed type 2 diabetes. Clin Endocrinol (Oxf) 2011; 75: 450-5.

[126] Reinehr T, Roth CL. Fetuin-A and its relation to metabolic syndrome and fatty liver disease in obese children before and after weight loss. J Clin Endocrinol Metab 2008; 93: 4479-85.

[127] Haukeland JW, Dahl TB, Yndestad A, et al. Fetuin A in nonalcoholic fatty liver disease: in vivo and in vitro studies. Eur J Endocrinol 2012; 166: 503-10.

[128] Shields WW, Thompson KE, Grice GA, Harrison SA, Coyle WJ. The Effect of Metformin and Standard Therapy versus Standard Therapy alone in Nondiabetic Patients with Insulin Resistance and Nonalcoholic Steatohepatitis (NASH): A Pilot Trial. Therap Adv Gastroenterol 2009; 2: 157-63.

[129] Kleiner DE, Brunt EM, Van Natta M, et al. Nonalcoholic Steatohepatitis Clinical Research Network. Design and validation of a histological scoring system for nonalcoholic fatty liver disease. Hepatology 2005; 41: 1313-21.

[130] Omer Z, Cetinkalp S, Akyildiz M, et al. Efficacy of insulinsensitizing agents in nonalcoholic fatty liver disease. Eur J Gastroenterol Hepatol 2010; 22: 18-23.

[131] Musso G, Cassader M, Rosina F, Gambino R. Impact of current treatments on liver disease, glucose metabolism and cardiovascular risk in non-alcoholic fatty liver disease (NAFLD): a systematic review and meta-analysis of randomized trials. Diabetologia 2012; 55: 885-904.

[132] Haukeland JW, Damås JK, Konopski Z, et al. Systemic inflammation in nonalcoholic fatty liver disease is characterized by elevated levels of CCL2. J Hepatol 2006; 44: 1167-74.

[133] Targher G. Relationship between high-sensitivity C-reactive protein levels and liver histology in subjects with non-alcoholic fatty liver disease. J Hepatol 2006; 45: 879-81; author reply 881-2.

[134] Bodmer M, Meier C, Krähenbühl S, Jick SS, Meier CR. Long-term metformin use is associated with decreased risk of breast cancer. Diabetes Care 2010; 33: 1304-8.

[135] Li D, Yeung SC, Hassan MM, Konopleva M, Abbruzzese JL. Antidiabetic therapies affect risk of pancreatic cancer. Gastroenterology $2009 ; 137$ : 482-8.

[136] Libby G, Donnelly LA, Donnan PT, Alessi DR, Morris AD, Evans JM. New users of metformin are at low risk of incident cancer: a cohort study among people with type 2 diabetes. Diabetes Care 2009; 32: 1620-5.

[137] Memmott RM, Mercado JR, Maier CR, Kawabata S, Fox SD, Dennis PA. Metformin prevents tobacco carcinogen--induced lung tumorigenesis. Cancer Prev Res (Phila) 2010; 3: 1066-76.

[138] Zhang ZJ, Zheng ZJ, Kan H, et al. Reduced risk of colorectal cancer with metformin therapy in patients with type 2 diabetes: a metaanalysis. Diabetes Care 2011; 34: 2323-8.

[139] Algire C, Moiseeva O, Deschênes-Simard X, et al. Metformin reduces endogenous reactive oxygen species and associated DNA damage. Cancer Prev Res (Phila) 2012; 5: 536-43.

[140] Bost F, Sahra IB, Le Marchand-Brustel Y, Tanti JF. Metformin and cancer therapy. Curr Opin Oncol 2012; 24: 103-8.

[141] Qu Z, Zhang Y, Liao M, Chen Y, Zhao J, Pan Y. In vitro and in vivo antitumoral action of metformin on hepatocellular carcinoma. Hepatol Res 2012 Mar 26. [Epub ahead of print]

[142] Shyangdan D, Clar C, Ghouri N, et al. Insulin sensitisers in the treatment of non-alcoholic fatty liver disease: a systematic review. Health Technol Assess 2011; 15: 1-110.

[143] Uygun A, Kadayifci A, Isik AT, et al. Metformin in the treatment of patients with non-alcoholic steatohepatitis. Aliment Pharmacol Ther 2004; 19: 537-44

[144] Nobili V, Manco M, Ciampalini P, et al Metformin use in children with nonalcoholic fatty liver disease: an open-label, 24-month, observational pilot study. Clin Ther 2008; 30: 1168-76.

[145] Haukeland JW, Konopski Z, Eggesbø HB, et al. Metformin in patients with non-alcoholic fatty liver disease: a randomized, controlled trial. Scand J Gastroenterol 2009; 44: 853-60.

[146] Fryer LG, Parbu-Patel A, Carling D. The Anti-diabetic drugs rosiglitazone and metformin stimulate AMP-activated protein kinase through distinct signaling pathways. J Biol Chem 2002; 277 25226-32.

[147] Bajaj M, Suraamornkul S, Piper P, et al. Decreased plasma adiponectin concentrations are closely related to hepatic fat content and hepatic insulin resistance in pioglitazone-treated type 2 diabetic patients. J Clin Endocrinol Metab 2004; 89: 200-6.

[148] Woods YL, Petrie JR, Sutherland C. Dissecting insulin signaling pathways: individualised therapeutic targets for diagnosis and treatment of insulin resistant states. Endocr Metab Immune Disord Drug Targets 2009; 9: 187-98

[149] Lutchman G, Promrat K, Kleiner DE, et al. Changes in serum adipokine levels during pioglitazone treatment for nonalcoholic steatohepatitis: relationship to histological improvement. Clin Gastroenterol Hepatol 2006; 4: 1048-52.

[150] Coletta DK, Sriwijitkamol A, Wajcberg E, et al. Pioglitazone stimulates AMP-activated protein kinase signalling and increases the expression of genes involved in adiponectin signalling, mitochondrial function and fat oxidation in human skeletal muscle in vivo: a randomised trial. Diabetologia 2009; 52: 723-32.

[151] Galli A, Ceni E, Mello T, et al. Thiazolidinediones inhibit hepatocarcinogenesis in hepatitis B virus-transgenic mice by peroxisome proliferator-activated receptor gamma-independent regulation of nucleophosmin. Hepatology 2010; 52: 493-505.

[152] Dormuth CR, Carney G, Carleton B, Bassett K, Wright JM. Thiazolidinediones and fractures in men and women. Arch Intern Med 2009; 169: 1395-402.

[153] Nissen SE, Wolski K. Effect of rosiglitazone on the risk of myocardial infarction and death from cardiovascular causes. N Engl J Med 2007; 356: 2457-71. Erratum in: N Engl J Med 20075; 357: 100 .

[154] Lonardo A, S. Sookoian M. Chonchol, P. Loria, G. Targher Cardiovascular and systemic risk in nonalcoholic fatty liver disease. Atherosclerosis as a major player in the natural course of NAFLD Curr Pharm Des 2012 In press.

[155] Colmers IN, Bowker SL, Majumdar SR, Johnson JA. Use of thiazolidinediones and the risk of bladder cancer among people with type 2 diabetes: a meta-analysis. CMAJ 2012 [Epub ahead of print].

[156] Sanyal AJ, Mofrad PS, Contos MJ, et al. A pilot study of vitamin E versus vitamin $\mathrm{E}$ and pioglitazone for the treatment of nonalcoholic steatohepatitis. Clin Gastroenterol Hepatol 2004; 2: 1107-15.

[157] Belfort R, Harrison SA, Brown K, et al. A placebo-controlled trial of pioglitazone in subjects with nonalcoholic steatohepatitis. N Engl J Med 2006; 355: 2297-307.

[158] Ratziu V, Giral P, Jacqueminet S, et al. LIDO Study Group. Rosiglitazone for nonalcoholic steatohepatitis: one-year results of 
the randomized placebo-controlled Fatty Liver Improvement with Rosiglitazone Therapy (FLIRT) Trial. Gastroenterology 2008; 135: 100-10.

[159] Aithal GP, Thomas JA, Kaye PV, et al. Randomized, placebocontrolled trial of pioglitazone in nondiabetic subjects with nonalcoholic steatohepatitis. Gastroenterology 2008; 135: 1176-84.

[160] Sanyal AJ, Chalasani N, Kowdley KV, et al. NASH CRN. Pioglitazone, vitamin $\mathrm{E}$, or placebo for nonalcoholic steatohepatitis. N Engl J Med 2010; 362: 1675-85.

[161] Promrat K, Lutchman G, Uwaifo GI, et al. A pilot study of pioglitazone treatment for nonalcoholic steatohepatitis. Hepatology 2004; 39: $188-96$

[162] Neuschwander-Tetri BA, Brunt EM, Wehmeier KR, Oliver D, Bacon BR. Improved nonalcoholic steatohepatitis after 48 weeks of treatment with the PPAR-gamma ligand rosiglitazone. Hepatology 2003; 38: 1008-17.

[163] Pan J, Chen C, Jin Y, et al. Differential impact of structurally different anti-diabetic drugs on proliferation and chemosensitivity of acute lymphoblastic leukemia cells. Cell Cycle 2012; 11: 2314-26.

[164] Yu J, Shen B, Chu ES, et al. Inhibitory role of peroxisome proliferator-activated receptor gamma in hepatocarcinogenesis in mice and in vitro. Hepatology 2010; 51: 2008-19.

[165] Chang CH, Lin JW, Wu LC, Lai MS, Chuang LM, Chan KA. Association of thiazolidinediones with liver cancer and colorectal cancer in type 2 diabetes mellitus. Hepatology 2012; 55: 1462-72.

[166] Shen B, Chu ES, Zhao G, et al. PPARgamma inhibits hepatocellular carcinoma metastases in vitro and in mice. Br J Cancer 2012; 106: 1486-94.

[167] Wu CW, Farrell GC, Yu J. Functional Role of PPAR $\gamma$ in Hepatocellular Carcinoma. J Gastroenterol Hepatol 2012 [Epub ahead of print].

[168] Hassan MM, Curley SA, Li D, Kaseb A, et al. Association of diabetes duration and diabetes treatment with the risk of hepatocellular carcinoma. Cancer 2010; 116: 1938-46.

[169] Chen TM, Lin CC, Huang PT, Wen CF. Metformin associated with lower mortality in diabetic patients with early stage hepatocellular carcinoma after radiofrequency ablation. J Gastroenterol Hepatol 2011; 26: 858-65.

[170] Nkontchou G, Cosson E, Aout M, et al. Impact of metformin on the prognosis of cirrhosis induced by viral hepatitis $\mathrm{C}$ in diabetic patients. J Clin Endocrinol Metab 2011; 96: 2601-8.

[171] Chen HP, Shieh JJ, Chang CC, et al. Metformin decreases hepatocellular carcinoma risk in a dose-dependent manner: populationbased and in vitro studies. Gut 2012 Jul 7. [Epub ahead of print]

[172] Neuschwander-Tetri BA. Hepatic lipotoxicity and the pathogenesis of nonalcoholic steatohepatitis: the central role of nontriglyceride fatty acid metabolites. Hepatology 2010; 52: 774-88

[173] ClinicalTrials.gov numbe NCT00633282

[174] Stockl KM, Le L, Zhang S, Harada AS. Risk of acute myocardial infarction in patients treated with thiazolidinediones or other antidiabetic medications. Pharmacoepidemiol Drug Saf 2009; 18: 166-74.

[175] Habib ZA, Tzogias L, Havstad SL, et al. Relationship between thiazolidinedione use and cardiovascular outcomes and all-cause mortality among patients with diabetes: a time-updated propensity analysis. Pharmacoepidemiol Drug Saf 2009; 18: 437-47.

[176] Dormandy JA, Charbonnel B, Eckland DJ, et al. PROactive investigator. Secondary prevention of macrovascular events in patients with type 2 diabetes in the PROactive Study (PROspective pioglitAzone Clinical Trial In macroVascular Events): a randomised controlled trial. Lancet 2005; 366; 1279-89.

[177] Lincoff AM, Wolski K, Nicholls SJ, Nissen SE. Pioglitazone and risk of cardiovascular events in patients with type 2 diabetes mellitus: a meta-analysis of randomized trials. JAMA 2007; 298: 11808 .

[178] DREAM (Diabetes REduction Assessment with ramipril and rosiglitazone Medication) Trial Investigators, Gerstein HC, Yusuf $\mathrm{S}$, Bosch $\mathrm{J}$, et al. Effect of rosiglitazone on the frequency of diabetes in patients with impaired glucose tolerance or impaired fasting glucose: a randomised controlled trial. Lancet 2006; 368: 1096105. Erratum in: Lancet 2006; 368: 1770.

[179] Singh S, Loke YK, Furberg CD. Long-term risk of cardiovascular events with rosiglitazone: a meta-analysis. JAMA 2007; 298: 118995.
[180] Schwartz AV, Sellmeyer DE, Vittinghoff E, et al. Thiazolidinedione use and bone loss in older diabetic adults. J Clin Endocrinol Metab 2006; 91: 3349-54.

[181] Kelly IE, Han TS, Walsh K, Lean ME. Effects of a thiazolidinedione compound on body fat and fat distribution of patients with type 2 diabetes. Diabetes Care. 1999; 22: 288-93. Erratum in: Diabetes Care 1999; 22: 536.

[182] Yki-Järvinen H. Thiazolidinediones. N Engl J Med 2004; 351: 1106-18.

[183] Nesto RW, Bell D, Bonow RO, et al. American Heart Association; American Diabetes Association. Thiazolidinedione use, fluid retention, and congestive heart failure: a consensus statement from the American Heart Association and American Diabetes Association. Circulation 2003; 108: 2941-8

[184] Mahady SE, Webster AC, Walker S, Sanyal A, George J. The role of thiazolidinediones in non-alcoholic steatohepatitis - a systematic review and meta analysis. J Hepatol 2011; 55: 1383-90.

[185] Durbin RJ. Thiazolidinedione therapy in the prevention/delay of type 2 diabetes in patients with impaired glucose tolerance and insulin resistance. Diabetes Obes Metab 2004; 6: 280-5.

[186] Schwimmer JB, Deutsch R, Kahen T, Lavine JE, Stanley C, Behling C. Prevalence of fatty liver in children and adolescents. Pediatrics 2006; 118: 1388-93.

[187] Loomba R, Sirlin CB, Schwimmer JB, Lavine JE. Advances in pediatric nonalcoholic fatty liver disease. Hepatology 2009; 50: 1282-93.

[188] Schwimmer JB, Behling C, Newbury R, et al. Histopathology of pediatric nonalcoholic fatty liver disease. Hepatology 2005; 42: 641-9.

[189] Molleston JP, White F, Teckman J, Fitzgerald JF. Obese children with steatohepatitis can develop cirrhosis in childhood. Am J Gastroenterol 2002; 97: 2460-2.

[190] Targher G. Non-alcoholic fatty liver disease, the metabolic syndrome and the risk of cardiovascular disease: the plot thickens. Diabet Med 2007; 24: 1-6.

[191] Schwimmer JB, Pardee PE, Lavine JE, Blumkin AK, Cook S Cardiovascular risk factors and the metabolic syndrome in pediatric nonalcoholic fatty liver disease. Circulation 2008; 118: 277-83.

[192] Alkhouri N, Carter-Kent C, Elias M, Feldstein AE. Atherogenic dyslipidemia and cardiovascular risk in children with nonalcoholic fatty liver disease. Clin Lipidol 2011; 6: 305-14.

[193] Manco M. Metabolic syndrome in childhood from impaired carbohydrate metabolism to nonalcoholic fatty liver disease. J Am Coll Nutr 2011; 30: 295-303

[194] Alisi A, Nobili V. Non-alcoholic fatty liver disease in children now: Lifestyle changes and pharmacologic treatments. Nutrition 2012; 28: 722-6.

[195] Lavine JE, Schwimmer JB, Van Natta ML, et al. Nonalcoholic Steatohepatitis Clinical Research Network. Effect of vitamin E or metformin for treatment of nonalcoholic fatty liver disease in children and adolescents: the TONIC randomized controlled trial. JAMA 2011; 305: 1659-68.

[196] Pacifico L, Nobili V, Anania C, Verdecchia P, Chiesa C. Pediatric nonalcoholic fatty liver disease, metabolic syndrome and cardiovascular risk. World J Gastroenterol 2011; 17: 3082-91.

[197] Nobili V, Sanyal AJ. Treatment of nonalcoholic fatty liver disease in adults and children: a closer look at the arsenal. J Gastroenterol 2012; 47: 29-36.

[198] Svegliati-Baroni G, Saccomanno S, Rychlicki C, et al. Glucagonlike peptide-1 receptor activation stimulates hepatic lipid oxidation and restores hepatic signalling alteration induced by a high-fat diet in nonalcoholic steatohepatitis. Liver Int 2011; 31: 1285-97.

[199] Trevaskis JL, Griffin PS, Wittmer C, et al. Glucagon-like peptide-1 receptor agonism improves metabolic, biochemical, and histopathological indices of nonalcoholic steatohepatitis in mice. Am J Physiol Gastrointest Liver Physiol 2012; 302: G762-72.

[200] Ding X, Saxena NK, Lin S, Gupta NA, Anania FA. Exendin-4, a glucagon-like protein-1 (GLP-1) receptor agonist, reverses hepatic steatosis in ob/ob mice. Hepatology 2006; 43: 173-81. Erratum in: Hepatology 2006; 44: 515.

[201] Gupta NA, Mells J, Dunham RM, Grakoui A, Handy J, Saxena NK, Anania FA. Glucagon-like peptide-1 receptor is present on human hepatocytes and has a direct role in decreasing hepatic steatosis in vitro by modulating elements of the insulin signaling pathway. Hepatology 2010; 51: 1584-92. 
[202] Klonoff DC, Buse JB, Nielsen LL, Guan X, Bowlus CL, Holcombe JH, Wintle ME, Maggs DG. Exenatide effects on diabetes, obesity, cardiovascular risk factors and hepatic biomarkers in patients with type 2 diabetes treated for at least 3 years. Curr Med Res Opin 2008; $24: 275-86$

[203] Tushuizen ME, Bunck MC, Pouwels PJ, van Waesberghe JH, Diamant M, Heine RJ. Incretin mimetics as a novel therapeutic option for hepatic steatosis. Liver Int 2006; 26: 1015-7.

[204] Mells JE, Fu PP, Sharma S, Olson D, Cheng L, Handy JA, Saxena NK, Sorescu D, Anania FA. Glp-1 analog, liraglutide, ameliorates hepatic steatosis and cardiac hypertrophy in C57BL/6J mice fed a Western diet. Am J Physiol Gastrointest Liver Physiol 2012; 302: G225-35.

[205] Xiao C, Bandsma RH, Dash S, Szeto L, Lewis GF. Exenatide, a glucagon-like peptide-1 receptor agonist, acutely inhibits intestinal lipoprotein production in healthy humans. Arterioscler Thromb Vasc Biol 2012; 32: 1513-9.

[206] Samson SL, Sathyanarayana P, Jogi M, et al. Exenatide decreases hepatic fibroblast growth factor 21 resistance in non-alcoholic fatty liver disease in a mouse model of obesity and in a randomised controlled trial. Diabetologia 2011; 54: 3093-100.

[207] ClinicalTrials.gov number, NCT01208649

[208] Schuppan D, Gorrell MD, Klein T, Mark M, Afdhal NH. The challenge of developing novel pharmacological therapies for nonalcoholic steatohepatitis. Liver Int 2010; 30: 795-808.

[209] Tahrani AA, Bailey CJ, Del Prato S, Barnett AH. Management of type 2 diabetes: new and future developments in treatment. Lancet 2011; 378: 182-97.

[210] Maiztegui B, Borelli MI, Madrid VG, et al. Sitagliptin prevents the development of metabolic and hormonal disturbances, increased $\beta$ cell apoptosis and liver steatosis induced by a fructose-rich diet in normal rats. Clin Sci (Lond) 2011; 120: 73-80.

[211] Iwasaki T, Yoneda M, Inamori M, et al. Sitagliptin as a novel treatment agent for non-alcoholic Fatty liver disease patients with type 2 diabetes mellitus. Hepatogastroenterology 2011; 58: 2103-5.

[212] Yilmaz Y, Yonal O, Deyneli O, Celikel CA, Kalayci C, Duman DG. Effects of sitagliptin in diabetic patients with nonalcoholic steatohepatitis. Acta Gastroenterol Belg 2012; 75: 240-4.

[213] Nagasawa T, Inada Y, Nakano S, et al. Effects of bezafibrate, PPAR pan-agonist, and GW501516, PPARdelta agonist, on development of steatohepatitis in mice fed a methionine-and cholinedeficient diet. Eur J Pharmacol 2006; 536: 182-91.

[214] Pang M, de la Monte SM, Longato L, et al. PPARdelta agonist attenuates alcohol-induced hepatic insulin resistance and improves liver injury and repair. J Hepatol 2009; 50: 1192-201.

[215] Reilly SM, Lee CH. PPAR delta as a therapeutic target in metabolic disease. FEBS Lett 2008; 582: 26-31.

[216] ClinicalTrials.gov identifier: NCT00841217

[217] Nogueiras R, Rohner-Jeanrenaud F, Woods SC, Tschöp MH. The endocannabinoid system and the control of glucose homeostasis. J Neuroendocrinol 2008; 20: 147-51.

[218] Van Gaal LF, Rissanen AM, Scheen AJ, Ziegler O, Rössner S; RIO-Europe Study Group. Effects of the cannabinoid-1 receptor blocker rimonabant on weight reduction and cardiovascular risk factors in overweight patients: 1-year experience from the RIOEurope study. Lancet 2005; 365: 1389-97. Erratum in: Lancet 2005; 366: 370

[219] Pi-Sunyer FX, Aronne LJ, Heshmati HM, Devin J, Rosenstock J. RIO-North America Study Group. Effect of rimonabant, a cannabinoid-1 receptor blocker, on weight and cardiometabolic risk factors in overweight or obese patients: RIO-North America: a randomized controlled trial. JAMA 2006; 295: 761-75. Erratum in: JAMA 2006; $295: 1252$.

[220] Janero DR, Makriyannis A. Cannabinoid receptor antagonists: pharmacological opportunities, clinical experience, and translational prognosis. Expert Opin Emerg Drugs 2009; 14: 43-65.

[221] Wei J, Qiu de K, Ma X. Bile acids and insulin resistance: implications for treating nonalcoholic fatty liver disease. J Dig Dis 2009; 10: 85-90.

[222] Trauner M, Claudel T, Fickert P, Moustafa T, Wagner M. Bile acids as regulators of hepatic lipid and glucose metabolism. Dig Dis 2010; $28: 220-4$

[223] Lindor KD, Kowdley KV, Heathcote EJ, et al. Ursodeoxycholic acid for treatment of nonalcoholic steatohepatitis: results of a randomized trial. Hepatology 2004; 39: 770-8.
[224] Spadaro L, Magliocco O, Spampinato D, et al. Effects of n-3 polyunsaturated fatty acids in subjects with nonalcoholic fatty liver disease. Dig Liver Dis 2008; 40: 194-9.

[225] Abel T, Fehér J, Dinya E, Eldin MG, Kovács A. Safety and efficacy of combined ezetimibe/simvastatin treatment and simvastatin monotherapy in patients with non-alcoholic fatty liver disease. Med Sci Monit 2009; 15: MS6-11.

[226] Nelson A, Torres DM, Morgan AE, Fincke C, Harrison SA. A pilot study using simvastatin in the treatment of nonalcoholic steatohepatitis: A randomized placebo-controlled trial. J Clin Gastroenterol 2009; 43: 990-4.

[227] Athyros VG, Tziomalos K, Gossios TD, et al. GREACE Study Collaborative Group. Safety and efficacy of long-term statin treatment for cardiovascular events in patients with coronary heart disease and abnormal liver tests in the Greek Atorvastatin and Coronary Heart Disease Evaluation (GREACE) Study: a post-hoc analysis. Lancet 2010; 376: 1916-22.

[228] Lonardo A, Loria P. If steatosis is the atherosclerosis of the liver, are statins the "aspirin" for steatosis? Dig Liver Dis 2012; 44: 4512 .

[229] Rolo AP, Teodoro JS, Palmeira CM. Role of oxidative stress in the pathogenesis of nonalcoholic steatohepatitis. Free Radic Biol Med 2012; 52: 59-69.

[230] Fraulob JC, Souza-Mello V, Aguila MB, Mandarim-de-Lacerda CA. Beneficial effects of rosuvastatin on insulin resistance, adiposity, inflammatory markers and non-alcoholic fatty liver disease in mice fed on a high-fat diet. Clin Sci (Lond) 2012; 123: 259-70.

[231] Chang CY, Argo CK, Al-Osaimi AM, Caldwell SH. Therapy of NAFLD: antioxidants and cytoprotective agents. J Clin Gastroenterol 2006; 40: S51-60.

[232] Lirussi F, Azzalini L, Orando S, Orlando R, Angelico F. Antioxidant supplements for non-alcoholic fatty liver disease and/or steatohepatitis. Cochrane Database Syst Rev 2007; (1): CD004996.

[233] Saxena NK, Ikeda K, Rockey DC, Friedman SL, Anania FA. Leptin in hepatic fibrosis: evidence for increased collagen production in stellate cells and lean littermates of ob/ob mice. Hepatology 2002; 35: 762-71.

[234] Adachi M, Brenner DA. High molecular weight adiponectin inhibits proliferation of hepatic stellate cells via activation of adenosine monophosphate-activated protein kinase. Hepatology 2008; 47: 677-85.

[235] Caligiuri A, Bertolani C, Guerra CT, et al. Adenosine monophosphate-activated protein kinase modulates the activated phenotype of hepatic stellate cells. Hepatology 2008; 47: 668-76.

[236] Xu A, Wang Y, Keshaw H, Xu LY, Lam KS, Cooper GJ. The fatderived hormone adiponectin alleviates alcoholic and nonalcoholic fatty liver diseases in mice. J Clin Invest 2003; 112: 91-100.

[237] Kadowaki T, Yamauchi T. Adiponectin and adiponectin receptors. Endocr Rev 2005; 26: 439-51

[238] Barb D, Williams CJ, Neuwirth AK, Mantzoros CS. Adiponectin in relation to malignancies: a review of existing basic research and clinical evidence. Am J Clin Nutr 2007; 86: s858-66.

[239] Handy JA, Saxena NK, Fu P, Lin S, Mells JE, Gupta NA, Anania FA. Adiponectin activation of AMPK disrupts leptin-mediated hepatic fibrosis via suppressors of cytokine signaling (SOCS-3). J Cell Biochem 2010; 110: 1195-207. Erratum in: J Cell Biochem 2011; 112: 734 .

[240] Sharma D, Wang J, Fu PP, et al. Adiponectin antagonizes the oncogenic actions of leptin in hepatocellular carcinogenesis. Hepatology 2010; 52: 1713-22.

[241] Sargin H, Sargin M, Gozu H, et al. Is adiponectin level a predictor of nonalcoholic fatty liver disease in nondiabetic male patients? World J Gastroenterol 2005; 11: 5874-7.

[242] Zelber-Sagi S, Ratziu V, Zvibel I, et al. The association between adipocytokines and biomarkers for nonalcoholic fatty liver diseaseinduced liver injury: a study in the general population. Eur J Gastroenterol Hepatol 2012; 24: 262-9.

[243] Buechler C, Wanninger J, Neumeier M. Adiponectin, a key adipokine in obesity related liver diseases. World J Gastroenterol 2011; 17: 2801-11.

[244] Mendez-Sanchez N, Chavez-Tapia NC, Villa AR, et al. Adiponectin as a protective factor in hepatic steatosis. World J Gastroenterol 2005; 11: 1737-41.

[245] Czaja MJ. Liver injury in the setting of steatosis: crosstalk between adipokine and cytokine. Hepatology 2004; 40: 19-22. 
[246] Polyzos SA, Kountouras J, Deretzi G, Zavos C, Mantzoros CS. The emerging role of endocrine disruptors in pathogenesis of insulin resistance: a concept implicating nonalcoholic fatty liver disease. Curr Mol Med 2012; 12: 68-82.

[247] Silver MK, O'Neill MS, Sowers MR, Park SK. Urinary bisphenol A and type-2 diabetes in U.S. adults: data from NHANES 20032008. PLoS One 2011; 6: e26868.

[248] Stubbins RE, Najjar K, Holcomb VB, Hong J, Núñez NP. Oestrogen alters adipocyte biology and protects female mice from adipocyte inflammation and insulin resistance. Diabetes Obes Metab 2012; 14: 58-66.

[249] Faulds MH, Zhao C, Dahlman-Wright K, Gustafsson JA. The diversity of sex steroid action: regulation of metabolism by estrogen signaling. J Endocrinol 2012; 212: 3-12.

[250] Tiano JP, Mauvais-Jarvis F. Molecular Mechanisms of Estrogen Receptors' Suppression of Lipogenesis in Pancreatic $\beta$-Cells. Endocrinology 2012; 153: 2997-3005.

[251] Ribas V, Nguyen MT, Henstridge DC, et al. Impaired oxidative metabolism and inflammation are associated with insulin resistance in ERalpha-deficient mice. Am J Physiol Endocrinol Metab 2010; 298: E304-19.

[252] Lonardo A, Trande P. Are there any sex differences in fatty liver? A study of glucose metabolism and body fat distribution. J Gastroenterol Hepatol 2000; 15: 775-82.

[253] Lonardo A, Carani C, Carulli N, Loria P. 'Endocrine NAFLD' a hormonocentric perspective of nonalcoholic fatty liver disease pathogenesis. J Hepatol 2006; 44: 1196-207.

[254] Carulli L, Lonardo A, Lombardini S, Marchesini G, Loria P. Gender, fatty liver and GGT. Hepatology 2006; 44: 278-9.

[255] Saphner T, Triest-Robertson S, Li H, Holzman P. The association of nonalcoholic steatohepatitis and tamoxifen in patients with breast cancer. Cancer 2009; 115: 3189-95.

[256] Jones H, Sprung VS, Pugh CJ, et al. Polycystic Ovary Syndrome with Hyperandrogenism is Characterized by an Increased Risk of Hepatic Steatosis, Compared to Nonhyperandrogenic PCOS Phenotypes and Healthy Controls, Independent of Obesity and Insulin Resistance. J Clin Endocrinol Metab 2012 Jul 26. [Epub ahead of print]

[257] Di Martino V, Lebray P, Myers RP, et al. Progression of liver fibrosis in women infected with hepatitis C: long-term benefit of estrogen exposure. Hepatology 2004; 40: 1426-33.

[258] Ricchi M, Bertolotti M, Anzivino C, et al. 17 Beta-estradiol prevents cytotoxicity from hydrophobic bile acids in HepG2 and WRL-68 cell cultures. J Gastroenterol Hepatol 2006; 21: 894-901.

[259] Tilg H, Moschen AR. Evolution of inflammation in nonalcoholic fatty liver disease: the multiple parallel hits hypothesis. Hepatology 2010; 52: 1836-46.

[260] Marchesini G, Moscatiello S, Agostini F, Villanova N, Festi D. Treatment of non-alcoholic fatty liver disease with focus on emerging drugs. Expert Opin Emerg Drugs 2011; 16: 121-36.

[261] Polyzos SA, Kountouras J, Zavos C, Deretzi G. Nonalcoholic fatty liver disease: multimodal treatment options for a pathogenetically multiple-hit disease. J Clin Gastroenterol 2012; 46: 272-84.

[262] Aljada A, Mousa SA. Metformin and neoplasia: implications and indications. Pharmacol Ther 2012; 133: 108-15.

[263] Yang X, So WY, Ma RC, et al. Use of thiazolidinedione and cancer risk in Type 2 diabetes: The Hong Kong diabetes registry. Diabetes Res Clin Pract 2012.

[264] Mikhail N. Safety of dipeptidyl peptidase 4 inhibitors for treatment of type 2 diabetes. Curr Drug Saf 2011; 6: 304-9.

[265] Patil HR, Al Badarin FJ, Shami HA, Bhatti SK, Lavie CJ, Bell DS, O'Keefe JH. Meta-Analysis of Effect of Dipeptidyl Peptidase-4 Inhibitors on Cardiovascular Risk in Type 2 Diabetes Mellitus. Am J Cardiol 2012 Jun 14.
[266] Kenny PR, Brady DE, Torres DM, Ragozzino L, Chalasani N, Harrison SA. Exenatide in the treatment of diabetic patients with non-alcoholic steatohepatitis: a case series. Am J Gastroenterol 2010; 105: 2707-9.

[267] Oderda G, Sifford-Wilson SM. Bringing Liraglutide to Market: A CER Case Study. J Manag Care Pharm 2012; 18: S12-8.

[268] Waser B, Rehmann R, Sanchez C, Fourmy D, Reubi JC. Glucosedependent insulinotropic polypeptide receptors in most gastroenteropancreatic and bronchial neuroendocrine tumors. J Clin Endocrinol Metab 2012; 97: 482-8.

[269] Mundil D, Cameron-Vendrig A, Husain M. GLP-1 receptor agonists: a clinical perspective on cardiovascular effects. Diab Vasc Dis Res 2012; 9: 95-108.

[270] Cussons AJ, Watts GF, Mori TA, Stuckey BG. Omega-3 fatty acid supplementation decreases liver fat content in polycystic ovary syndrome: a randomized controlled trial employing proton magnetic resonance spectroscopy. J Clin Endocrinol Metab 2009; 94 : 3842-8.

[271] Nseir W, Mograbi J, Ghali M. Lipid-lowering agents in nonalcoholic Fatty liver disease and steatohepatitis: human studies. Dig Dis Sci 2012; 57: 1773-81.

[272] Wierzbicki AS, Oben J. Nonalcoholic fatty liver disease and lipids. Curr Opin Lipidol 2012.

[273] Heart Protection Study Collaborative Group. MRC/BHF Heart Protection Study of cholesterol lowering with simvastatin in 20,536 high-risk individuals: a randomised placebo-controlled trial. Lancet 2002; 360: 7-22.

[274] Cholesterol Treatment Trialists' Ctt Collaborators. The effects of lowering LDL cholesterol with statin therapy in people at low risk of vascular disease: meta-analysis of individual data from 27 randomised trials. Lancet 2012.

[275] Voican CS, Perlemuter G. Insulin resistance and oxidative stress: two therapeutic targets in non-alcoholic steatohepatitis. J Hepatol 2011; 54: 388-91.

[276] Yfanti C, Nielsen AR, Akerström T, et al. Effect of antioxidant supplementation on insulin sensitivity in response to endurance exercise training. Am J Physiol Endocrinol Metab 2011; 300: E76170.

[277] Dolara P, Bigagli E, Collins A. Antioxidant vitamins and mineral supplementation, life span expansion and cancer incidence: a critical commentary. Eur J Nutr 2012.

[278] Ratziu V, de Ledinghen V, Oberti F, et al. FRESGUN. A randomized controlled trial of high-dose ursodesoxycholic acid for nonalcoholic steatohepatitis. J Hepatol 2011; 54: 1011-9.

[279] Eaton JE, Silveira MG, Pardi DS, et al. High-dose ursodeoxycholic acid is associated with the development of colorectal neoplasia in patients with ulcerative colitis and primary sclerosing cholangitis. Am J Gastroenterol 2011; 106: 1638-45.

[280] Georgescu EF, Ionescu R, Niculescu M, Mogoanta L, Vancica L. Angiotensin-receptor blockers as therapy for mild-to-moderate hypertension-associated non-alcoholic steatohepatitis. World J Gastroenterol 2009; 15: 942-54.

[281] Yoshiji H, Kuriyama S, Kawata M, et al. The angiotensin-Iconverting enzyme inhibitor perindopril suppresses tumor growth and angiogenesis: possible role of the vascular endothelial growth factor. Clin Cancer Res 2001; 7: 1073-8.

[282] Kaibori M, Ishizaki M, Matsui K, Kitade H, Matsui Y, Kwon AH. Evaluation of metabolic factors on the prognosis of patients undergoing resection of hepatocellular carcinoma. J Gastroenterol Hepatol $2011 ; 26: 536-43$.

[283] Bhaskaran K, Douglas I, Evans S, van Staa T, Smeeth L. Angiotensin receptor blockers and risk of cancer: cohort study among people receiving antihypertensive drugs in UK General Practice Research Database. BMJ 2012; 344: e2697. 